\title{
Hydrometallurgical Processing of a Nigerian Galena Ore in Nitric Acid: Characterization and Dissolution Kinetics
}

\author{
Ikechukwu A. Nnanwube*, Okechukwu D. Onukwuli \\ Department of Chemical Engineering, Nnamdi Azikiwe University, Awka, Nigeria \\ Email: ${ }^{\star}$ ik.nnanwube@gmail.com
}

How to cite this paper: Nnanwube, I.A. and Onukwuli, O.D. (2018) Hydrometallurgical Processing of a Nigerian Galena Ore in Nitric Acid: Characterization and Dissolution Kinetics. Journal of Minerals and Materials Characterization and Engineering, 6, 271-293.

https://doi.org/10.4236/jmmce.2018.63020

Received: March 1, 2018

Accepted: May 1, 2018

Published: May 4, 2018

Copyright $\odot 2018$ by authors and Scientific Research Publishing Inc. This work is licensed under the Creative Commons Attribution International License (CC BY 4.0).

http://creativecommons.org/licenses/by/4.0/

\section{Open Access}

\begin{abstract}
The physico-chemical characterization and dissolution kinetics study of a $\mathrm{Ni}$ gerian galena ore in nitric acid has been undertaken. The effects of acid concentration, temperature, particle size, stirring speed and solid/liquid ratio on the leaching of galena were investigated. The X-ray fluorescence data showed that the galena ore used in the study exists mainly as $\mathrm{PbS}$. Lead $(\mathrm{Pb})$ was detected as the major metal for galena with metals such as $\mathrm{Na}, \mathrm{Ca}, \mathrm{Fe}, \mathrm{Zn}, \mathrm{Al}$ and $\mathrm{Mg}$ occurring as minor elements. The XRD analysis also confirmed the originality of the galena ore as it revealed that galena exists mainly as lead sulphide (PbS). The Fourier transform infrared (FTIR) analysis also supported the XRF and XRD analysis by revealing the presence of sulphur in the ore. The scanning electron micrograph (SEM) analysis revealed a high level of crystallinity of the ore. Results of the leaching studies showed that galena dissolution in nitric acid $\left(\mathrm{HNO}_{3}\right)$ increases with increasing concentration of nitric acid, temperature and stirring rate, and decreases with increasing particle diameter and solid/liquid ratio. In $10 \mathrm{M} \mathrm{HNO}_{3}$ at a temperature of $90^{\circ} \mathrm{C}$ using $75 \mu \mathrm{m}$ particle diameter with solid/liquid ratio of $20 \mathrm{~g} / \mathrm{L}$ and stirring speed of 540 rpm, about $84.5 \%$ of galena was dissolved in 150 minutes. The values of activation energy, order of reaction and Arrhenius constant calculated at the conditions above for galena were $27.01 \mathrm{KJ} / \mathrm{mol}, 0.93,26.71 \mathrm{~s}^{-1}$ respectively. The mechanism of dissolution of galena was established to follow the shrinking core model for the diffusion controlled mechanism, with surface chemical reaction as the rate controlling step for the leaching process. Finally, the XRD analysis of the post-leaching residue revealed the presence of gahnite and anglesite.
\end{abstract}

\section{Keywords}

Galena, Nigeria, Characterization, Leaching, Dissolution Kinetics, Nitric Acid 


\section{Introduction}

Galena, also called lead glance, is the natural mineral form of lead (II) sulphide. It is the most important ore of lead and an important source of silver. It is one of the most abundant and widely distributed sulphide minerals. It crystallizes in the cubic crystal system often showing octahedral forms. It is often associated with the minerals sphalerite, calcite and fluorite [1].

In general, many occurrences of the lead and zinc ores are known in Nigeria, Such as those of Ameka, Ameri and Enyigba near Abakaliki, at Benue and Zurak to name only few. It is estimated that there are at least 30 lodes within an aggregate length of about $600 \mathrm{~m}$ as detailed [2] [3].

Lead metal has several useful mechanical properties, including high density, low melting point, ductility, and relative inertness [4]. Lead has been used for bullets since their invention in the middle ages. It is inexpensive; its low melting point means small arms ammunition and shot gun pellets can be cast with minimal technical equipment; and it is denser than other common metals, which allows for better retention of velocity.

Its high density and resistance to corrosion have been exploited in a number of related applications. It is used as ballast in sailboat kneels [5]. Its weight allows it to counterbalance the heeling effect of wind on the sails; being so dense it takes up a small volume and minimizes water resistance. It is used in Scuba diving weight belts to counteract the diver's buoyancy [6]. Because of its corrosion resistance, lead is used as a protective sheath for underwater cables [7].

In general, the recovery of lead from galena via a hydrometallurgical route has been studied by several investigators under various chemical conditions. A hydrometallurgical alternative has been sought because of the growing concern about the adverse environmental impact of high-temperature processing of galena as detailed by Feurstenau et al. [8]. A detailed review of some previous studies on the characterization and dissolution kinetics of galena varieties in acid and oxidative reagents is presented in the following sections.

\subsection{Galena Ore Characterization}

Several studies on the characterization of galena ore have been carried out in the recent past. Some of the reported results on the composition of galena from different parts of the world are summarized in Table 1.

Galena is composed of lead as a dominant metal followed by sulphur, iron and zinc in that order. The composition of galena varies from one location to another. The different values can be accounted for by the variation in geochemical and environmental effects. The richest galena was found in Japan as reported by Awakura et al. [9], Nigeria: Olanipekun [10] and USA: Feurstenau et al. [8]; while the poorest was in Mexico: Makita et al. [11] and China: Wang et al. [12].

\subsection{Galena Dissolution Kinetic Studies}

Aydogan et al. [13] investigated the kinetics of galena dissolution in nitric acid 
Table 1. Elemental composition (\%) of galena mineral from various origin.

\begin{tabular}{|c|c|c|c|c|c|c|c|c|c|c|c|c|c|c|}
\hline \multirow{2}{*}{ Reference } & \multirow{2}{*}{ Origin } & \multicolumn{13}{|c|}{ Major elemental composition (\%) } \\
\hline & & $\mathrm{Pb}$ & $\mathrm{Zn}$ & $\mathrm{Fe}$ & S & $\mathrm{Cu}$ & As & $\mathrm{Sb}$ & $\mathrm{Bi}$ & $\mathrm{Si}$ & $\mathrm{Al}$ & $\mathrm{Ca}$ & $\mathrm{Na}$ & $\mathrm{Ag}$ \\
\hline Abraitts et al. [23] & United Kingdom & 65.0 & 4.10 & 7.50 & 19.60 & - & - & - & - & - & - & - & - & 0.13 \\
\hline Awakura et al. [9] & Japan & 84.50 & - & - & 13.36 & - & - & - & - & - & - & - & - & - \\
\hline Aydogan et al. [18] & Sivas, Turkey & 79.00 & 1.90 & 2.97 & 14.61 & - & 0.50 & - & - & - & - & - & - & - \\
\hline Cisneros-Gonzalez et al. [24] & Penoles, Mexico & 54.75 & 4.75 & 5.25 & 14.80 & - & - & - & - & - & - & - & - & - \\
\hline Feurstenau et al. [8] & Kansas, USA & 85.60 & - & - & 13.0 & - & - & - & - & - & - & - & - & - \\
\hline Harvey and Yen [25] & Gourvenour Canada & 75.40 & 3.90 & 31.80 & 8.10 & 0.5 & - & - & - & - & - & - & - & - \\
\hline Makita et al. [11] & Chihvahua, Mexico & 49.76 & 2.48 & 14.75 & 23.53 & 0.29 & 3.85 & 0.51 & - & - & - & - & - & - \\
\hline Olanipekun [10] & Abakaliki, Nigeria & 85.20 & 1.03 & 0.48 & 13.90 & 0.02 & - & - & - & 0.06 & 0.04 & 0.18 & 0.04 & - \\
\hline Pacholewska [26] & $\begin{array}{l}\text { ZHG, Proles Law, } \\
\text { S/Africa }\end{array}$ & 69.30 & 2.44 & 6.21 & 18.4 & - & - & - & - & 0.05 & - & 0.77 & - & - \\
\hline Silva [1] & Callagham, Australia & 60.90 & 15.20 & 3.93 & 19.70 & - & - & - & - & - & - & - & - & 0.13 \\
\hline Wang et al. [12] & China & 54.10 & 1.17 & 10.29 & 18.08 & - & - & 0.05 & 0.04 & - & - & - & - & - \\
\hline
\end{tabular}

-: Not analyzed.

solutions with hydrogen peroxide. The galena used was obtained from Sivas, Turkey. 0.5 $\mathrm{M} \mathrm{HNO}_{3}$ was used, in the presence of $1 \mathrm{M} \mathrm{H}_{2} \mathrm{O}_{2}$. The temperature range used was $27^{\circ} \mathrm{C}-60^{\circ} \mathrm{C}$. The activation energy was calculated to be 42.26 $\mathrm{KJ} / \mathrm{mol}$ while the reaction order was calculated as 0.92 .

Warren et al. [14] investigated the effect of chloride ion on the ferric chloride leaching of galena concentrate, using galena obtained from Alabama, Tuscaloosa. $0.2 \mathrm{M} \mathrm{FeCl}_{3}$ was used in the presence of $4 \mathrm{M} \mathrm{NaCl}$ and $0.1 \mathrm{M} \mathrm{HCl}$. The temperature range used was $27^{\circ} \mathrm{C}-57^{\circ} \mathrm{C}$. The activation energy was estimated to be $72.10 \mathrm{KJ} / \mathrm{mol}$ while the reaction order was calculated as 0.21 .

Baba and Adekola [15] carried out a comparative study of the dissolution kinetics of the galena ore in binary solutions of $\mathrm{FeCl}_{3} / \mathrm{HCl}$ and $\mathrm{H}_{2} \mathrm{O}_{2} / \mathrm{HCl}$. The dissolution kinetics of the galena was found to depend on leachant concentration, reaction temperature, and stirring speed, while it decreases with the increase of solid-to-liquid ratio and particle diameter. The activation energy $\left(\mathrm{E}_{\mathrm{a}}\right)$ of $26.5 \mathrm{KJ} / \mathrm{mol}$ was obtained for galena ore dissolution in $0.3 \mathrm{M} \mathrm{FeCl}_{3} / 8.06 \mathrm{M} \mathrm{HCl}$, and it suggests the surface diffusion model for the leaching reaction, while the $\mathrm{E}_{\mathrm{a}}$ value of $40.6 \mathrm{KJ} / \mathrm{mol}$ was obtained for its dissolution in $8.06 \mathrm{M} \mathrm{H}_{2} \mathrm{O}_{2} / 8.06 \mathrm{M}$ $\mathrm{HCl}$, which suggests the surface chemical reaction model for the leaching reaction. Furthermore, the linear relationship between rate constants and the reciprocal of the particle radius supports the fact that dissolution is controlled by the surface reaction in the two cases. Finally, the rate of reaction based on the reaction-controlled process was described by a semi-empirical mathematical model. The Arrhenius and reaction constants of $11.023 \mathrm{~s}^{-1}, 1.25 \times 10^{4}$ and $3.65 \times$ $10^{2}, 8.02 \times 10^{6}$ were calculated for the $0.3 \mathrm{M} \mathrm{FeCl}_{3} / 8.06 \mathrm{M} \mathrm{HCl}$ and $8.06 \mathrm{M}$ $\mathrm{H}_{2} \mathrm{O}_{2} / 8.06 \mathrm{M} \mathrm{HCl}$ binary solutions respectively. 
Liu et al. [16] studied the acidic, non-oxidative dissolution of galena (PbS) nanocrystals using transmission electron microscopy (TEM) to follow the evolution of the size and shape of the nanocrystals before and after dissolution experiments, X-ray photoelectron spectroscopy (XPS) to follow particle chemistry, and dissolution rate analysis to compare dissolution rates between nanocrystalline and bulk galena. Dissolution characteristics were also studied as a function of nanocrystals access to bulk versus confined solution due to the degree of proximity of next-nearest grains. Detailed XPS analysis showed the nanocrystals to be free of unwanted contamination, surface complexes, and oxidative artifacts, except for small amounts of lead-containing oxidation species in both preand post-dissolution samples which have been observed in fresh, natural bulk galena.

According to Gerson and O'Dea [17], surface species found on galena during oxidation and dissolution has been studied using many techniques. It has been assumed that complexation takes place at the surface of hydrous galena sulphides. The adsorption of $\mathrm{H}^{+}$ions onto a surface of the $\mathrm{S}$ atom in the aqueous phase is found to be favourable, whereas the adsorption unto the surface of $\mathrm{Pb}$ atom is not favourable as suggested by Aydogan et al. [18]. In view of the above reasons, the dissolution rates are often analyzed with the shrinking core models which state that the leaching process is controlled by:

1) the diffusion of the reactant through the solution boundary layer or through a solid product layer; or

2) by the rate of chemical reaction; or

3) by mixed controlled process, which are chemical and diffusion controlled reactions as reported by Baba [19], Levenspiel [20] and Merwe [21].

Therefore, understanding the mechanism of a leaching system is an important aspect of this work, while a knowledge of the kinetics of the rate controlling process and solid reaction products are crucial for a complete understanding of the system as evidenced by Aydogan et al. [18].

The non-oxidative leaching of the base metal sulphide ore including galena in acidic solution, releasing hydrogen sulphide has been studied in various laboratories and tested in pilot plants as demonstrated by Awakura et al. [9].

Generally, there are insufficient kinetic studies to explain the complete mechanism of the dissolution of galena in nitric acid solution in the literature. Most of the available dissolution studies did not address some basic important kinetic parameters such as reaction order, activation energy, Arrhenius factors and correlation constant. This often makes the proposition of the dissolution mechanism difficult. Results of selected kinetic studies on galena dissolution extracted from literature are summarized in Table 4.

It is evident from Table 4 that most of the kinetics parameters necessary for the prediction of the actual dissolution mechanism (activation energy, reaction order, residual product, etc.) were lacking and thus making the mechanism proposition to be ambiguously difficult. Consequently, the scope of this investi- 
gation is to address these problems. Due to the increased demand for lead in Nigeria and other developing countries of the world, there is the need to develop simple and practicable routes for the recovery of this valuable metal from Nigerian galena ore which is among the richest in the world [22].

\section{Materials and Methods}

The galena ore used for this study was collected from Abakaliki, Enyigba mining site in Ebonyi State of Nigeria. The galena ore was finely pulverized and sieved into five fractions: $75,106,212,300$, and $425 \mu \mathrm{m}$. All experiments were performed with $75 \mu \mathrm{m}$ fraction except otherwise stated. Solutions of $\mathrm{HNO}_{3}$ were prepared from analytical grade reagents with deionized water.

\subsection{Characterization of the Ore}

\subsubsection{Spectrophotometric Analysis}

The X-ray fluorometer (XRF), X-supreme 600 oxford instruments was used for the elemental analysis of the ore. The mineralogical analysis of the ore was done using ARL X'TRA X-ray Diffractometer, Thermoscientific with the serial number 197492086 and Empyrean by PanAnalytical model with CuKa (1.54 ̊̊) radiation generated and $40 \mathrm{~mA}$ and $45 \mathrm{kV}$. This unit comprises of a single compact cabinet. The cabinet houses a high speed, high precision Goniometer; high efficiency generator (X-ray) and an automatic sample loading facility.

The petrographic slides of galena ore were prepared using Epoxy and Lakeside 70 media according to the method of Hutchison [27].

\subsubsection{FTIR and SEM Analysis}

FTIR analysis was carried out using Buck Scientific M530 Infrared Spectrophotometer. SEM analysis was carried out using Q250 by FEI model from the Netherlands.

\subsection{Leaching Procedure}

Leaching experiments were performed in a $500 \mathrm{ml}$ glass reactor fitted with a condenser to prevent losses through evaporation. The two major variables (heat and stirring rate) necessary for accelerating the rate of chemical reaction was provided by the aid of a magnetically-stirred hot plate (Model 78HW-1). For every leaching experiment, the solution mixture was freshly prepared by dissolving $20 \mathrm{~g} / \mathrm{L}$ of the ore sample in the acid solution at $90^{\circ} \mathrm{C}$. The concentration which gave the maximum dissolution was subsequently used to study other leaching parameters including temperature and particle size. At the end of each reaction time, the undissolved materials in the suspension was allowed to settle and separated by filtration. The resulting solutions were diluted and analyzed for lead using atomic absorption spectrophotometer (AAS).

The mole fraction of lead passing into the solution from galena was calculated by the formula given in Equation (1), where $x$ designates quantity dissolution. 


$$
x=\frac{\text { Amount of } \mathrm{Pb} \text { passing into the solution }}{\text { Amount of } \mathrm{Pb} \text { in original sample }}
$$

The activation energy, $E_{a}$, and rate constants were evaluated from the Arrhenius plots. The post-leached residues after dissolution in the optimum conditions were subjected to XRD and SEM examination.

\section{Results and Discussion}

\subsection{Results of Characterization Studies}

\subsubsection{Elemental Composition by XRF}

The results of the elemental composition of galena by X-ray fluorescence technique showed that the galena mineral exist mainly as $\mathrm{PbS}$ with metals such as $\mathrm{Na}, \mathrm{Mg}, \mathrm{Al}, \mathrm{Ca}, \mathrm{Fe}$ and $\mathrm{Zn}$ occurring as minor elements, and $\mathrm{K}, \mathrm{Cr}$, and $\mathrm{Sr}$ as traces. The elemental analysis gave $\mathrm{Pb}(60.01 \%), \mathrm{S}$ (14.66\%), $\mathrm{Fe}(4.32 \%), \mathrm{Na}$ (3.78\%), Si (7.69\%), Mg (1.21\%), Al (1.94\%), P (1.37\%), Cl (1.19\%), K (0.09\%), $\mathrm{Ca}(1.99 \%), \mathrm{Cr}(0.01 \%), \mathrm{Mn}(0.49 \%), \mathrm{Zn}(1.22 \%)$, and $\mathrm{Sr}(0.04 \%)$.

\subsubsection{Phase Studies by XRD}

The analysis of galena by X-ray diffraction gives a better description in terms of the mineral phases present in the ore. Table 2 present the results of the X-ray diffractogram of the ore and shows that the ore exist mainly as lead sulphide $(\mathrm{PbS})$.

The galena ore gave three major peaks at $2.96,3.42$, and $2.09 \AA$, respectively as shown in Figure 1. All these supported the results of the elemental analysis by XRF.

\subsubsection{FTIR Analysis of Galena}

The FTIR spectra of galena ore is shown in Figure 2. The spectrum of the ore exhibit absorption bands at $3821 \mathrm{~cm}^{-1}, 3652 \mathrm{~cm}^{-1}, 3353 \mathrm{~cm}^{-1}, 2958 \mathrm{~cm}^{-1}$, and $2564 \mathrm{~cm}^{-1}$. These are attributed to O-H stretching. The band at $1410 \mathrm{~cm}^{-1}$ is attributed to $\mathrm{O}-\mathrm{H}$ bending. The bands at $3519 \mathrm{~cm}^{-1}, 3353 \mathrm{~cm}^{-1}$ and $2564 \mathrm{~cm}^{-1}$ are attributed to N-H stretching. The band at $2564 \mathrm{~cm}^{-1}$ which is attributed to $\mathrm{S}-\mathrm{H}$

Table 2. The X-ray diffraction data of the galena ore showing the angle $2 \theta$ and d-values of the compounds identified, with their relative intensity (\%).

\begin{tabular}{ccccc}
\hline $2 \theta$ & d-Value $(\AA)$ & Compound & Intensity $(\%)$ & JCPDS file No. \\
\hline 26.03 & 3.42 & Galena $(\mathrm{PbS})$ & 93.99 & $01-078-1056$ \\
30.15 & 2.96 & Galena $(\mathrm{PbS})$ & 100.00 & $01-078-1056$ \\
43.16 & 2.09 & Galena $(\mathrm{PbS})$ & 65.77 & $01-078-1056$ \\
51.10 & 1.79 & Galena $(\mathrm{PbS})$ & 38.14 & $01-078-1056$ \\
53.55 & 1.71 & Galena $(\mathrm{PbS})$ & 20.72 & $01-078-1056$ \\
62.68 & 1.48 & Galena $(\mathrm{PbS})$ & 8.71 & $01-078-1056$ \\
69.06 & 1.36 & Galena $(\mathrm{PbS})$ & 12.91 & $01-078-1056$ \\
\hline
\end{tabular}

JCPDS File No.: Joint Committee on Power Diffraction Standards File Number. 


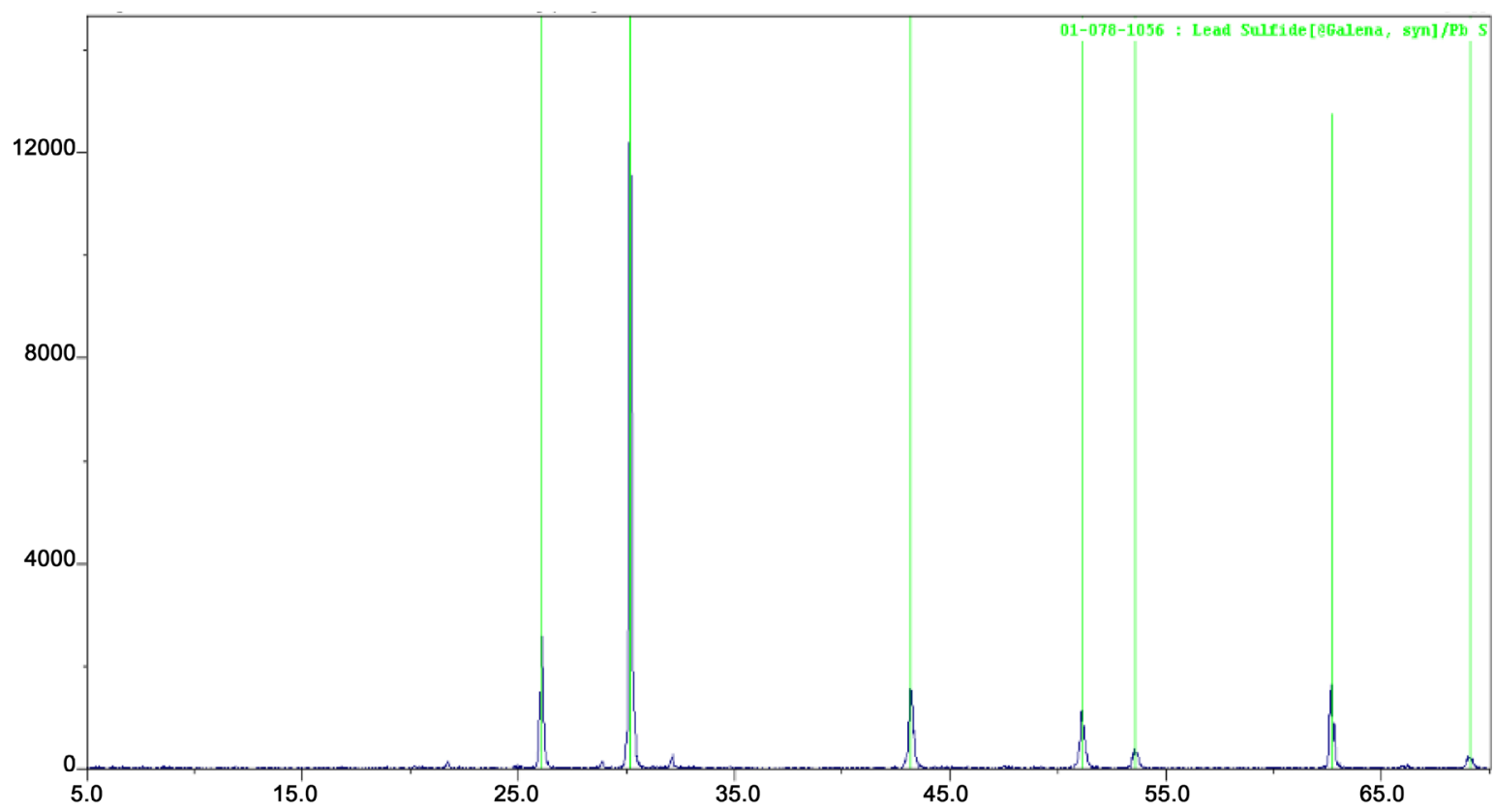

Figure 1. X-ray diffraction pattern of galena ore.

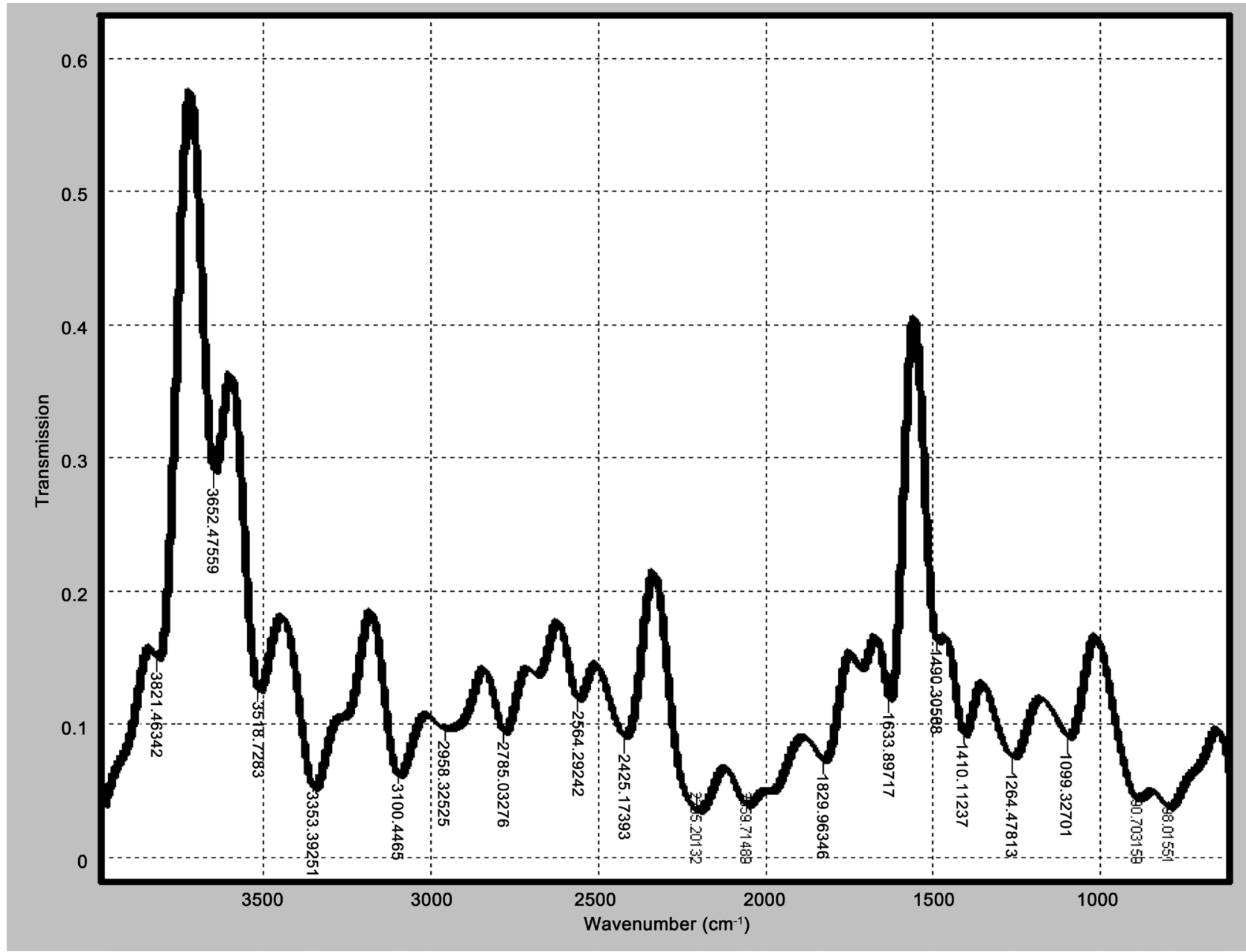

Figure 2. FTIR spectrum of galena ore. 
stretching confirms the presence of sulphur in the ore. The band at $1634 \mathrm{~cm}^{-1}$ is attributed to $\mathrm{Si}-\mathrm{O}$ and $\mathrm{Al}-\mathrm{O}$ stretching while the band at $1634 \mathrm{~cm}^{-1}$ is also attributed to Al-O-H stretching.

The FTIR result is in agreement with XRF and XRD results which confirmed the presence of the minerals detected.

\subsubsection{SEM Analysis of Galena}

The scanning electron micrograph (SEM) of galena ore was obtained with magnifications of 240x, 520x, 1000x, and 1500x respectively as shown in Figure 3.

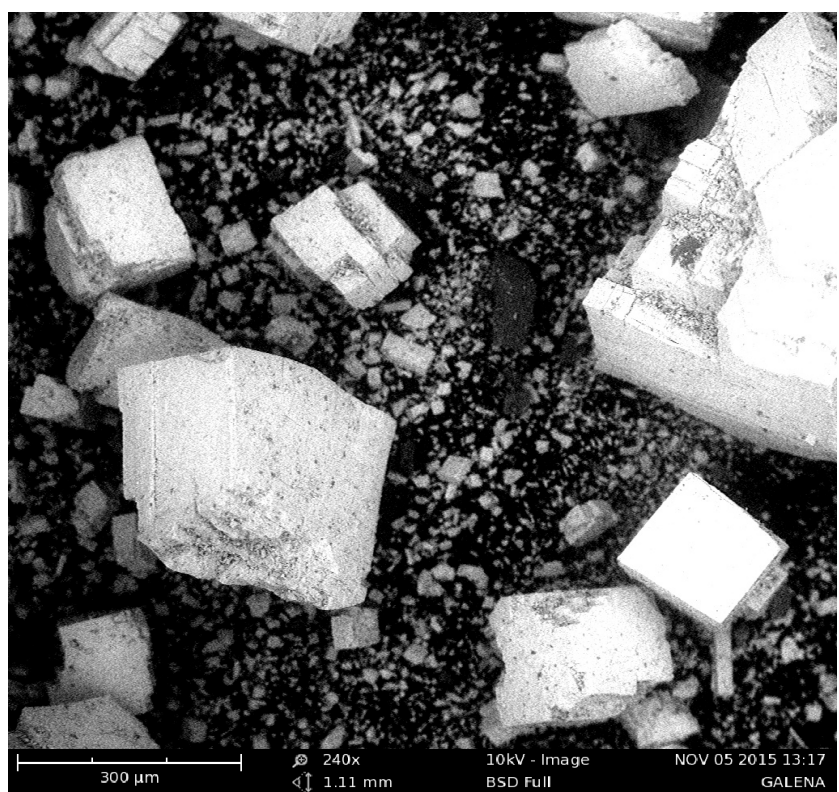

(a)

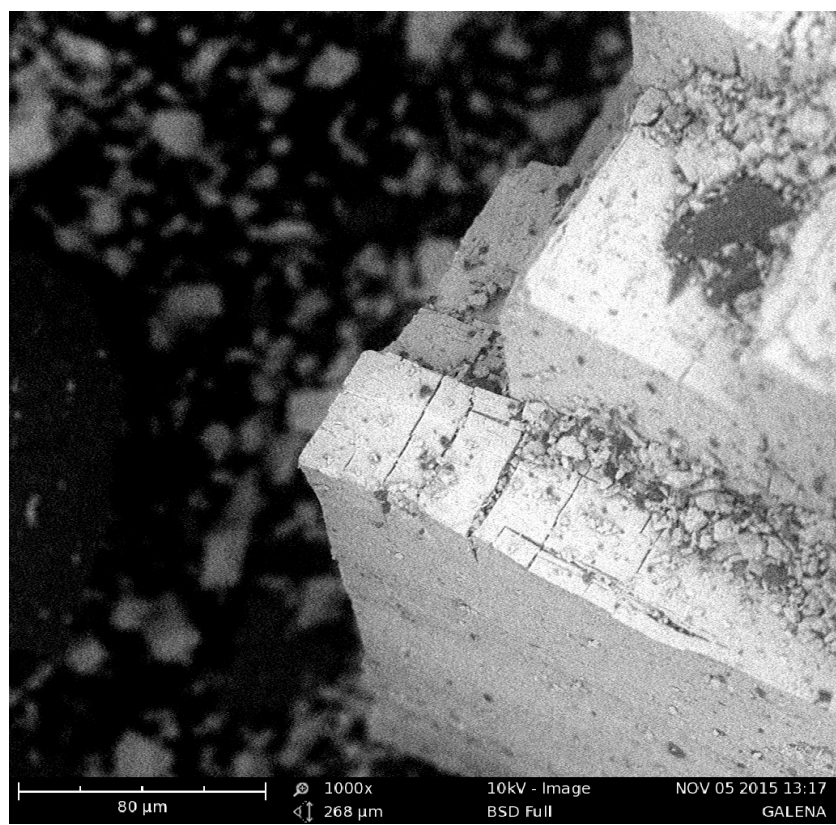

(c)

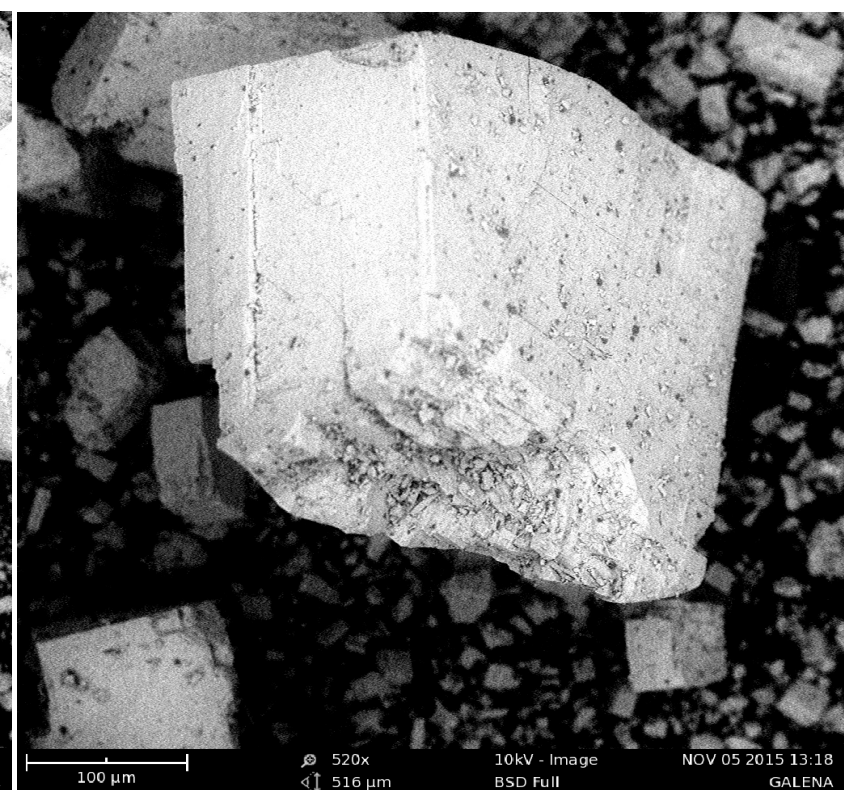

(b)

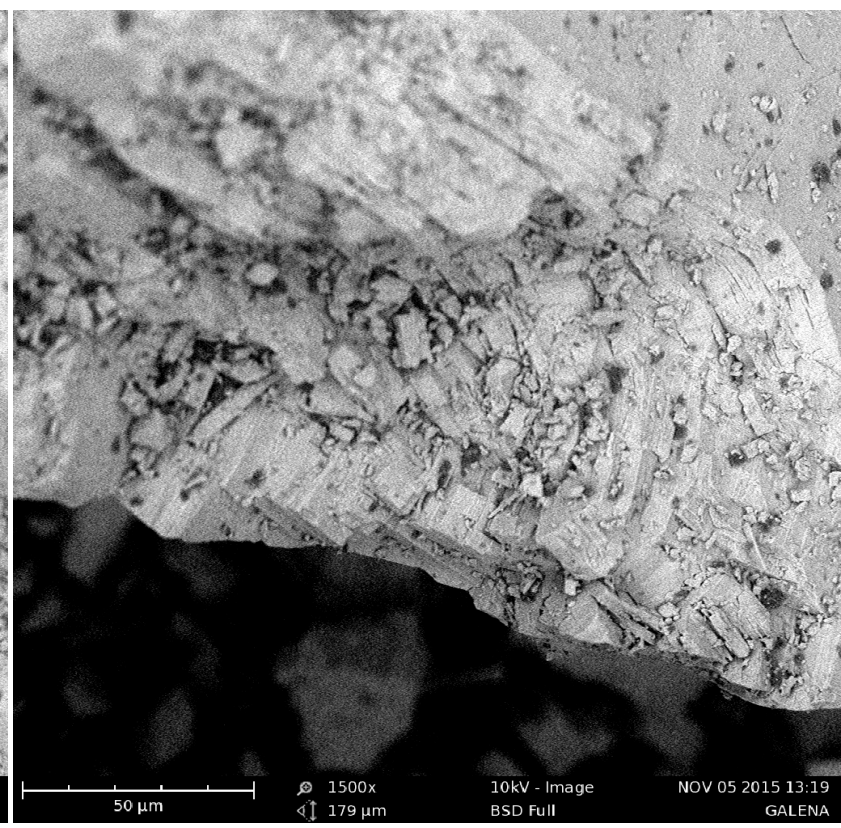

(d)

Figure 3. SEM images of galena ore showing magnifications of $240 \times(a), 520 \times(b), 1000 \times(c)$, and $1500 \times(d)$ respectively. 
The average cell diameter of the ore ranges from 8 to $62 \mu \mathrm{m}$ while the average cell density ranges from 0.0042 to 1.13 cells $/ \mathrm{mm}$. The results indicate that the ore particles are very cohesive, forming an aggregate mass that appeared to have been formed by several flaky particles stacked together in form of agglomerates [28]. The particles have irregular shapes with rough edges, and are highly crystalline due to the high level of purity of the ore.

\subsection{Leaching Studies}

\subsubsection{Effect of $\mathrm{HNO}_{3}$ Concentration on Galena Dissolution}

The results of the effect of $\mathrm{HNO}_{3}$ concentration on galena dissolution are illustrated in Figure 4. The result shows that the fraction of galena dissolved increases with increasing acid concentration. The yield of lead obtained with $12 \mathrm{M}$ $\mathrm{HNO}_{3}$ is slightly lower than that obtained with $10 \mathrm{M} \mathrm{HNO}_{3}$, and this could be attributed to a change in the rate determining step due to the significant quantity of elemental sulphur produced [14].

In all cases, unreacted acid remained in the leach solution and the free acid increased with increasing initial acid concentration, since the use of more concentrated acid did not increase the dissolution of galena or decrease the leaching time for maximum dissolution. Therefore, $10 \mathrm{M} \mathrm{HNO}_{3}$ was used for further investigation.

\subsubsection{Effect of Stirring Rate on Galena Dissolution}

The results on the effect of stirring rate on galena dissolution in $10 \mathrm{M} \mathrm{HNO}_{3}$ over the range of $90-720 \mathrm{rpm}$ at $363 \mathrm{~K}$ are presented in Figure 5.

Figure 5 shows that the amount of galena dissolved is dependent on the stirring speed over the range $90-540 \mathrm{rpm}$. Above $540 \mathrm{rpm}$, the stirring speed no

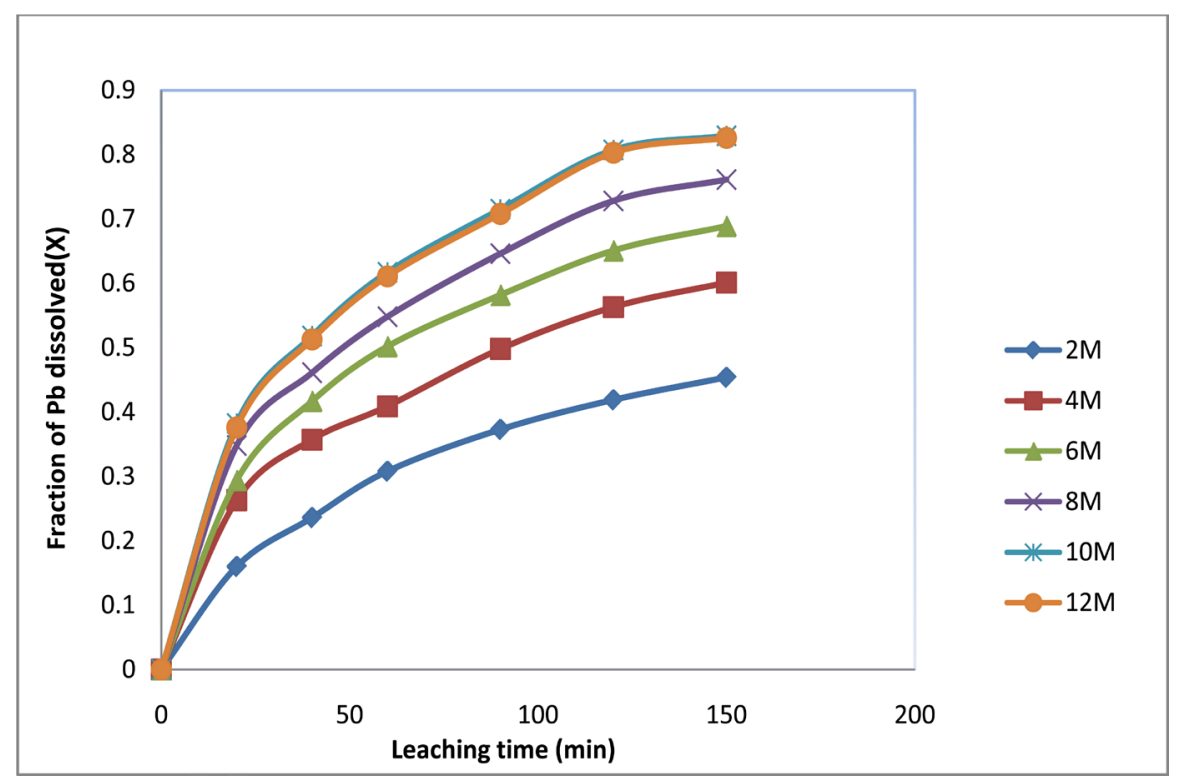

Figure 4. Effect of $\mathrm{HNO}_{3}$ concentration on galena dissolution at various leaching time. Experimental conditions: particle size $=75 \mu \mathrm{m}$; solid/liquid ratio $=20 \mathrm{~g} / \mathrm{L}$; temperature $=$ $333 \mathrm{~K}$; stirring speed $=450 \mathrm{rpm}$. 
longer has any observable effect on the solid dissolution. Hence dissolution reached a steady rate at $540 \mathrm{rpm}$, and a stirring speed of $540 \mathrm{rpm}$ was retained for further experiments. Increase in stirring speed causes a decrease in the thickness of the film layer, therefore, causing an increase in the dissolution rate [29].

\subsubsection{Effect of Temperature on Galena Dissolution}

The effect of temperature on galena dissolution has been investigated over the temperature range $303-363 \mathrm{~K}$ in $10 \mathrm{M} \mathrm{HNO}_{3}$ solution at a stirring rate of 540 $\mathrm{rpm}$ using $75 \mu \mathrm{m}$ particle diameter and solid/liquid ratio of $20 \mathrm{~g} / \mathrm{L}$. These results are presented in Figure 6.

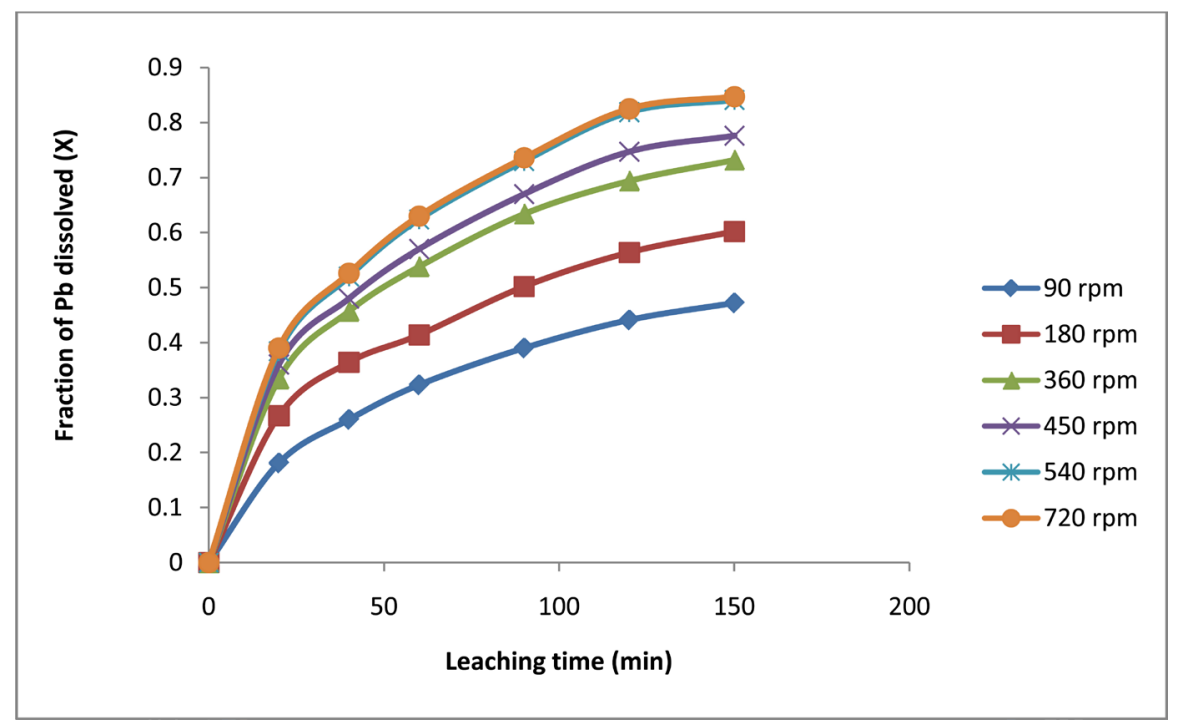

Figure 5. Effect of stirring rate on galena dissolution at various leaching time. Experimental conditions: particle size $=75 \mu \mathrm{m}$; solid/liquid ratio $=20 \mathrm{~g} / \mathrm{L}$; temperature $=363 \mathrm{~K}$; $\mathrm{HNO}_{3}$ concentration $=10 \mathrm{M}$.

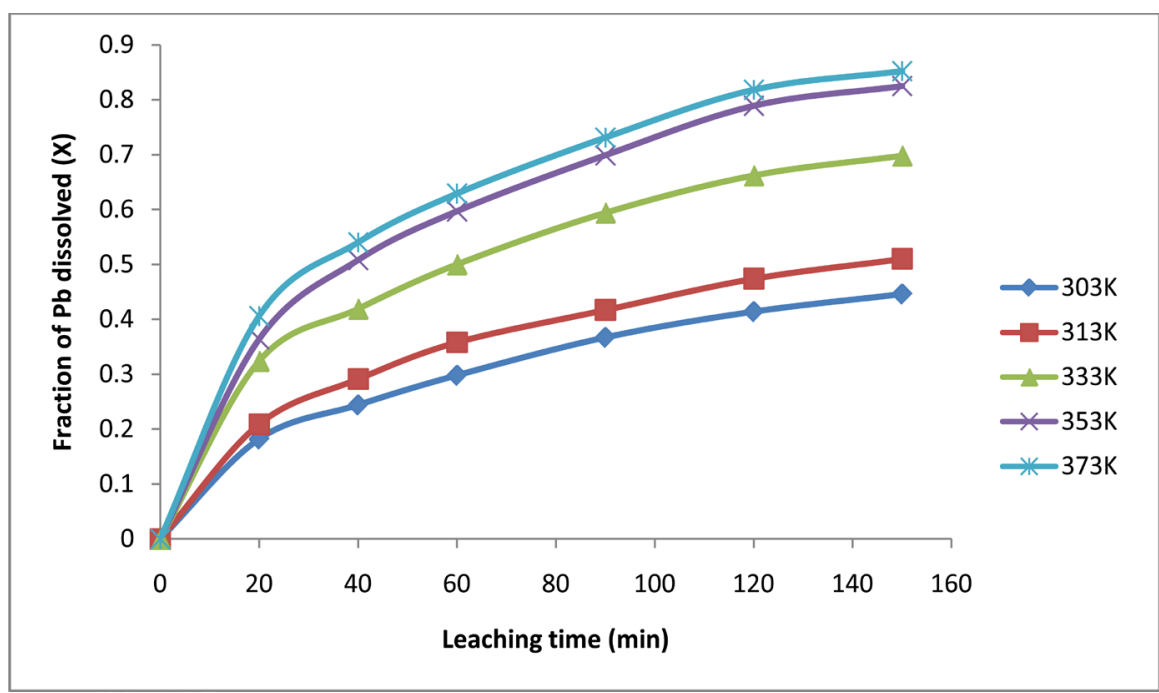

Figure 6. Fraction of galena dissolved vs. leaching time at different temperatures. Experimental conditions: particle size $=75 \mu \mathrm{m}$; solid/liquid ratio $=20 \mathrm{~g} / \mathrm{L}$; stirring rate $=540$ rpm; $\mathrm{HNO}_{3}$ concentration $=10 \mathrm{M}$. 
As seen in Figure 6, galena dissolution increases with increasing temperature. This is as a result of high kinetic energy available for the reacting molecules [29]. For instance, at $363 \mathrm{~K}$, the amount of galena dissolved within $150 \mathrm{~min}$ was $85.2 \%$.

\subsubsection{Effect of Particle Diameter on Galena Dissolution}

The influence of particle diameter on galena dissolution in $\mathrm{HNO}_{3}$ was investigated for five different sized fractions. The results are summarized in Figure 7.

The results from Figure 7 showed that the smaller the galena particle size, the higher was the fraction of galena dissolved. This is attributed to larger specific surface area provided by the smaller particles for contact with the acid molecules [29]. This observation was also supported by Aydogan et al. [13] and Dutrizac and MacDonald [30].

\subsubsection{Effect of Solid/Liquid Ratio on Galena Dissolution}

The results on the effect of solid/liquid ratio on galena dissolution in $10 \mathrm{M} \mathrm{HNO}_{3}$ were investigated in the range 0.02 to $0.045 \mathrm{~g} / \mathrm{ml}$ at a temperature of $363 \mathrm{~K}$.

Figure 8 shows the effect of solid/liquid ratio on galena dissolution in $10 \mathrm{M}$ $\mathrm{HNO}_{3}$. Decreasing the solid/liquid ratio is accompanied with increase in the equilibrium percentage of the ore dissolved. For instance, by varying the sol$\mathrm{id} /$ liquid ratio from 0.045 to $0.02 \mathrm{~g} / \mathrm{ml}$, the percentage of galena dissolved increased from $47 \%$ to $84 \%$ at $363 \mathrm{~K}$. This could be attributed to the decrease in the fluid reactant per unit weight of the solid [29]. Accordingly, an optimum solid/liquid ratio of $0.02 \mathrm{~g} / \mathrm{ml}$ has been retained for subsequent studies.

\subsection{Discussions}

\subsubsection{Dissolution Kinetic Models}

For this study, three shrinking core models were tested for better understanding

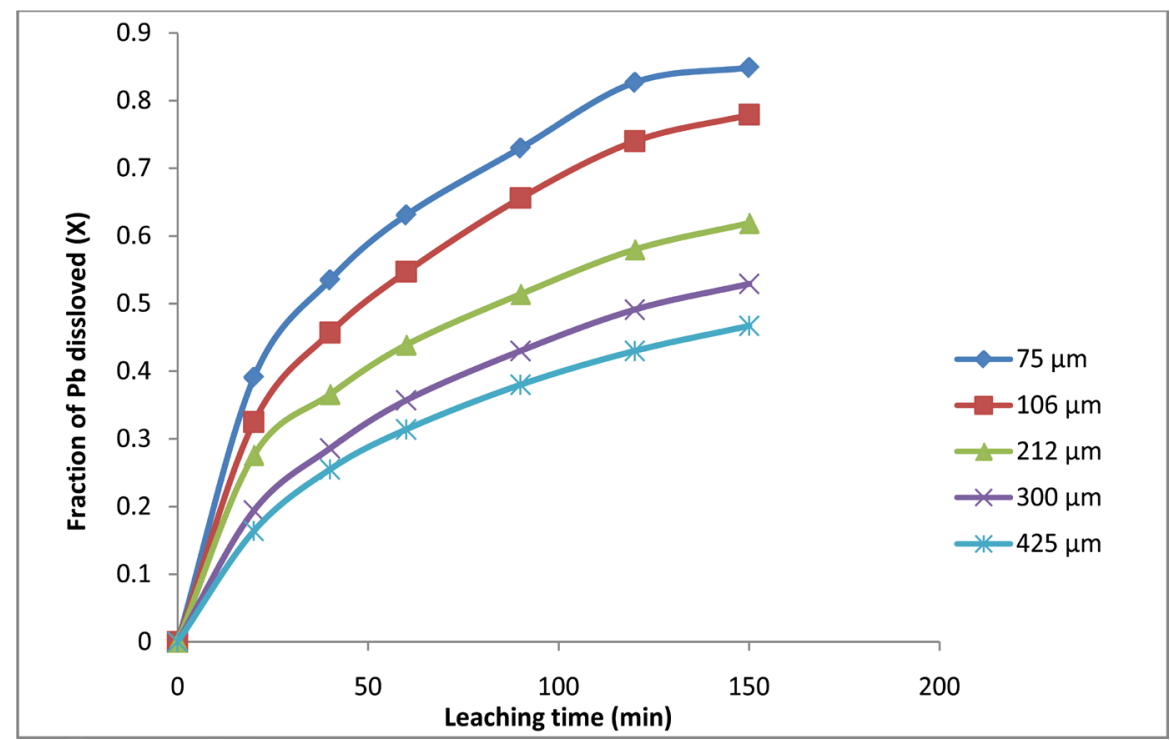

Figure 7. Effect of particle diameter on galena dissolution. Experimental conditions. $\mathrm{HNO}_{3}$ concentration $=10 \mathrm{M}$; solid/liquid ratio $=20 \mathrm{~g} / \mathrm{L}$; stirring rate $=540 \mathrm{rpm}$; temperature $=363 \mathrm{~K}$. 


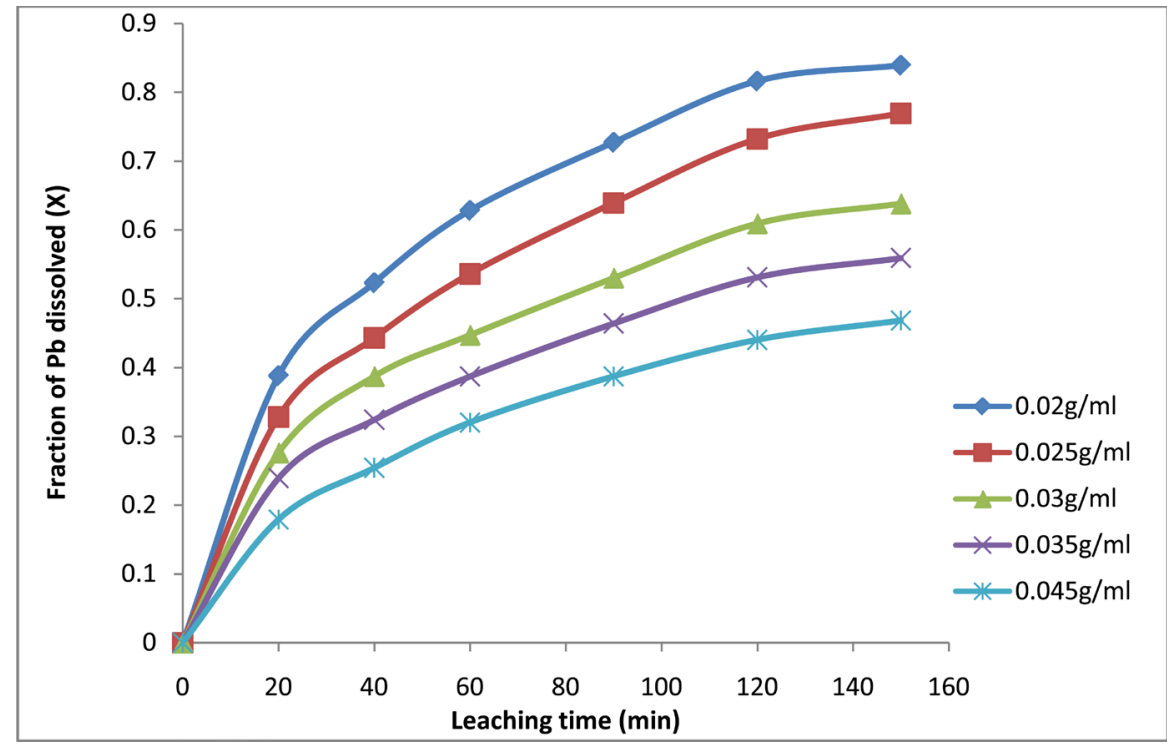

Figure 8. Effect of solid/liquid ratio on galena dissolution. Experimental conditions. $\mathrm{HNO}_{3}$ concentration $=10 \mathrm{M}$; particle size $=75 \mu \mathrm{m}$; stirring rate $=540 \mathrm{rpm}$; temperature $=363 \mathrm{~K}$.

of the dissolution of galena in $\mathrm{HNO}_{3}$ media. The kinetic models as previously utilized by some authors such as Aydogan et al. [13] [18], Baba and Adekola [31], Habashi [32], Khalique et al. [33], Leao [34] and Merwe [21] include:

$$
\begin{gathered}
1-(1-X)^{1 / 3}=\frac{b k_{s} C_{A}}{\rho_{s} r_{o}} t=k_{2} t \\
1+2(1-X)-3(1-X)^{2 / 3}=\frac{6 b D_{e} C_{A}}{\rho_{s} r_{o}^{2}} t=k_{3} t \\
1-(1-X)^{1 / 3}+(y / 6)\left[(1-X)^{1 / 3}+1-2(1-X)^{2 / 3}\right]=k_{4} t
\end{gathered}
$$

where $X$ is the fraction of galena dissolved at time t, $b$ the stoichiometric coefficient of the reagent in the leaching reaction, $k_{s}$ the kinetic constant, $C_{A}$ the concentration of nitric acid $\left(\mathrm{HNO}_{3}\right), \rho_{s}$ the density of the solid, $r_{o}$ the initial radius of the solid, and $k_{2}$ the rate constant from Equation (2). $D_{\epsilon}$ is the effective diffusion coefficient, $k_{3}$ and $k_{4}$ are the rate constants for Equations ((3) and (4)) respectively, $y$ is taken to be 1 for heterogeneous systems.

Equation (2) is applicable to a chemical reaction controlled process at the interface; Equation (3) is a diffusion-controlled process through the product layer and Equation (4) is a mixed controlled process (a combination of surface reaction and diffusion). Of all the three models tested, all the studied data were found only to fit the relation in Equation (3) with a perfect correlation of about 0.99 . The analysis of the plots of other kinetic curves, however, gave lower correlation coefficients. Hence, the linearization of Figures 4-8 was made. To this end, the relation: $1+2(1-X)-3(1-X)^{2 / 3}=k_{1} t$, gave an average correlation coefficient of 0.994 and this is shown in Figure 9.

From Figure 9, the experimental rate constant $k_{1}$, was calculated from the 
slope of the straight line at various $\mathrm{HNO}_{3}$ concentrations and the plots of $\operatorname{In} k_{1}$ versus $\operatorname{In}\left[\mathrm{HNO}_{3}\right]$ are shown in Figure 10.

From Figure 10, the slope of the resulting plot gave 0.93. This shows that the order of reaction with respect to $\mathrm{H}^{+}$ion concentration is 0.93 with correlation coefficient of 0.990 .

Similarly, the apparent rate constant $k_{5}$ was calculated from the slope of the straight line at various stirring rates $(w)$ as shown in Figure 11 and the plots of In $k_{5}$ versus In $w$ are shown in Figure 12.

Furthermore, the data in Figure 6 at different temperatures were linearized by Equation (3). This is shown in Figure 13. The data in Figure 7 and Figure 8 were also linearized by means of Equation (3) as shown in Figure 15 and Figure 16 respectively.

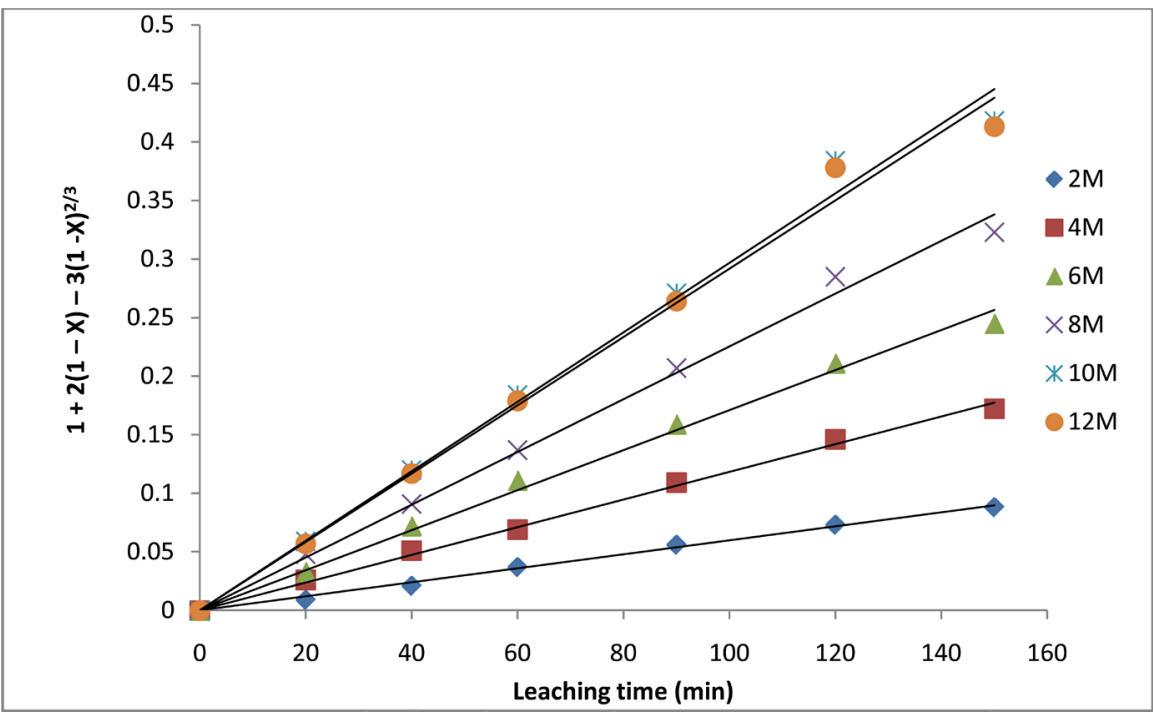

Figure 9. Plot of $1+2(1-X)-3(1-X)^{2 / 3}=k t$ vs. leaching time at various $\mathrm{HNO}_{3}$ concentrations for data presented in Figure 4.

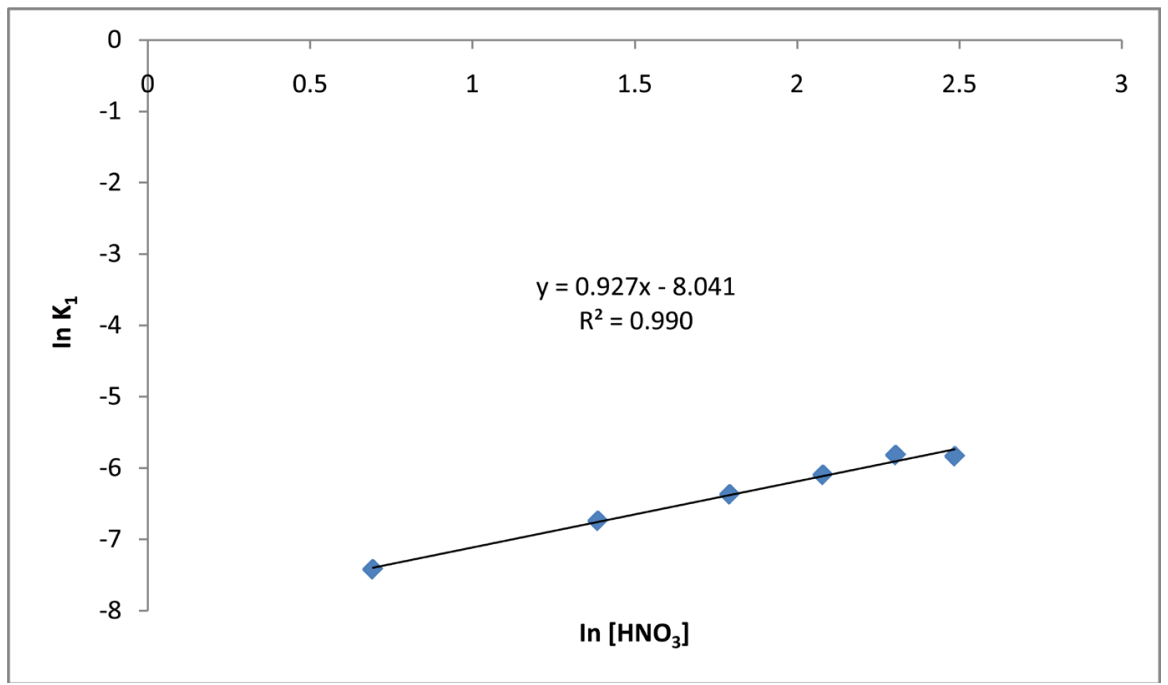

Figure 10. Plot of $\operatorname{In} k_{1}$ vs. In $\left[\mathrm{HNO}_{3}\right]$, for determining order of acid concentration. 


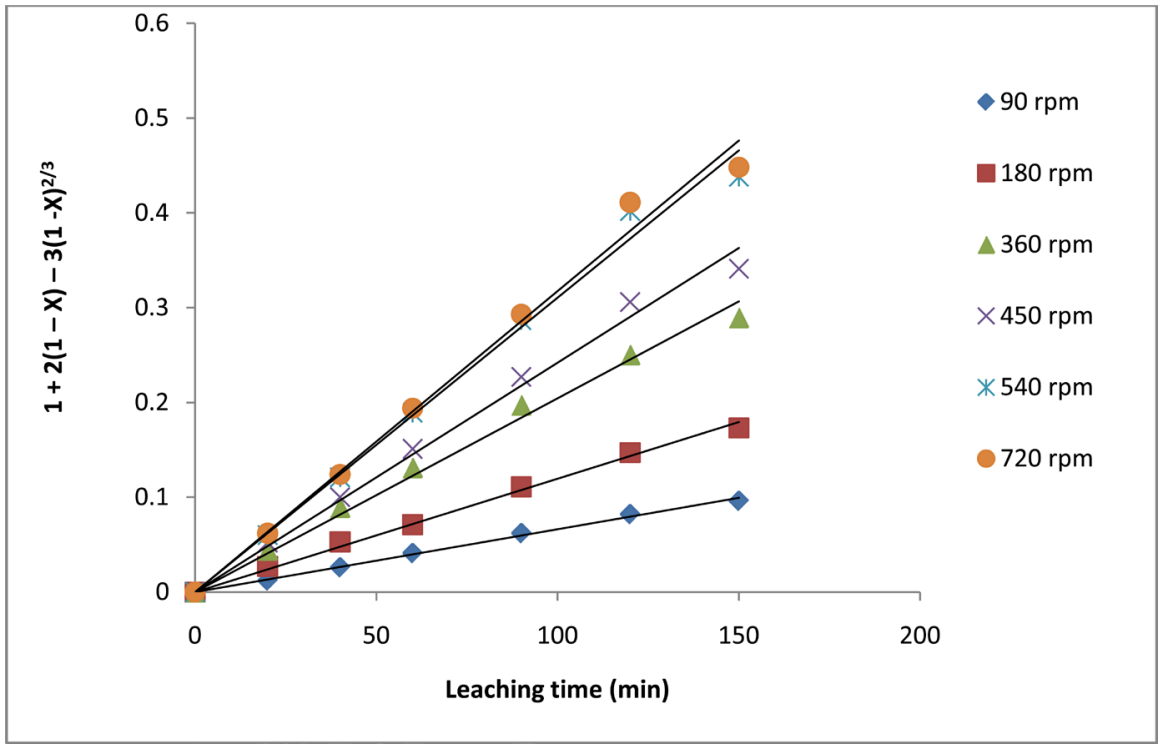

Figure 11. Plot of $1+2(1-X)-3(1-X)^{2 / 3}=k t$ vs. leaching time at various stirring rates for data presented in Figure 5.

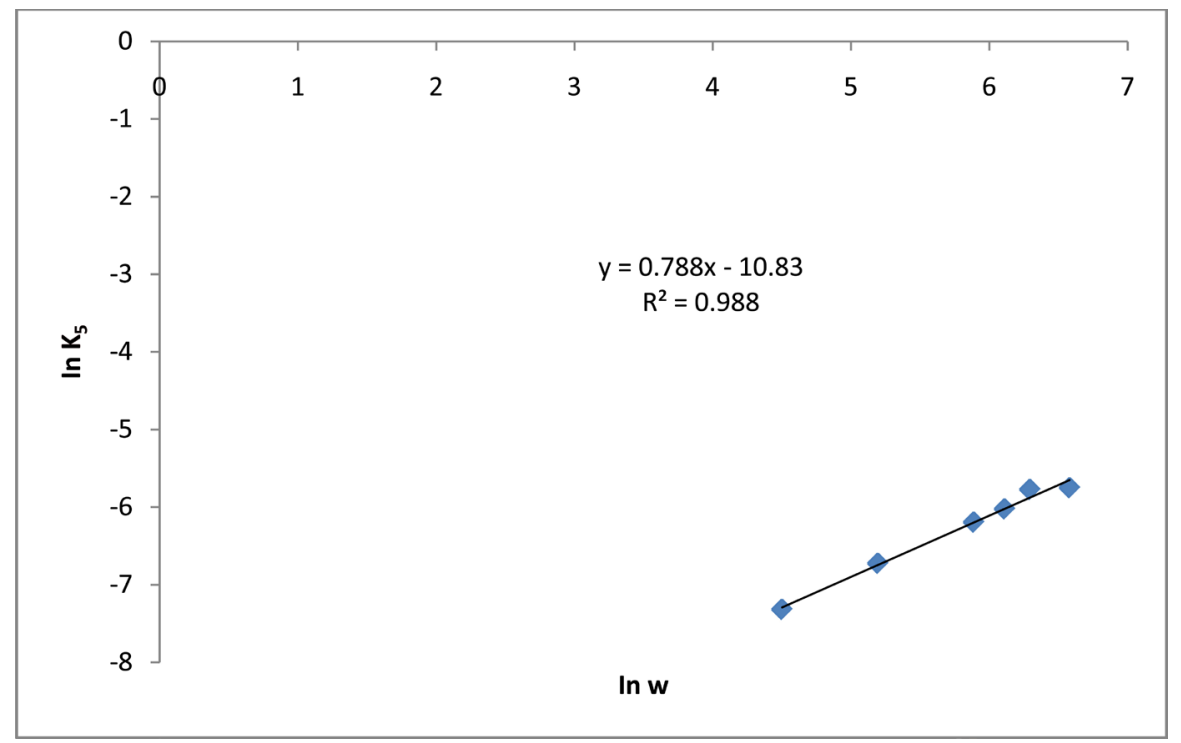

Figure 12. Plot of In $k_{5}$ vs. In $w$, for determining order of stirring rate.

From Figure 13, the apparent rate constants, $k_{3}$ and other tested constants, $k_{2}$ and $k_{4}$ were calculated from the slopes of the straight lines. The values of these rate constants with their equivalent correlation coefficients are summarized in Table 3.

By using the rate constants derived from the slopes in Figure 13, the Arrhenius diagram in Figure 14 was plotted from which the activation energy of 27.01 $\mathrm{KJ} / \mathrm{mol}$ was calculated, which supports the proposed diffusion controlled mechanism. The Arrhenius constant for the process was estimated to be $26.71 \mathrm{~s}^{-1}$ with a correlation coefficient of 0.985 . In some instances and as reported by Olanipekun [35], the rate controlling mechanism of the heterogeneous dissolution 


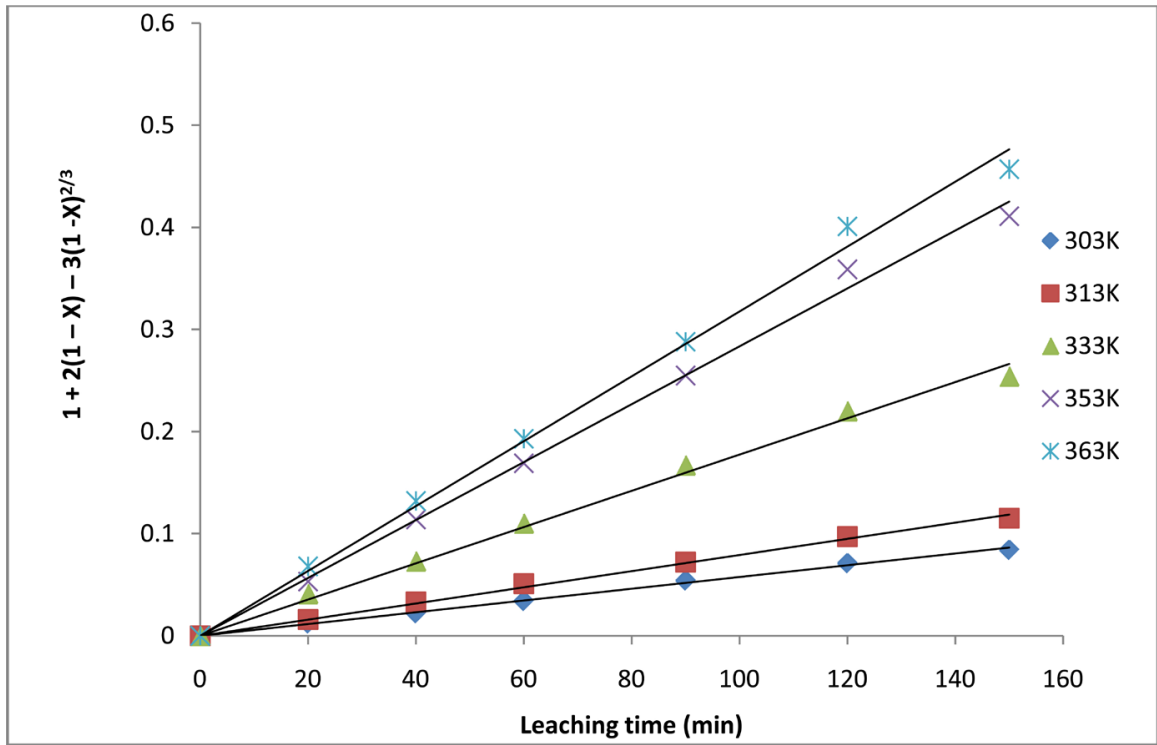

Figure 13. Plot of $1+2(1-X)-3(1-X)^{2 / 3}=k t$ vs. leaching time at various temperatures for data presented in Figure 6.

Table 3. The values of rate constants $k_{2}, k_{3}$ and $k_{4}$ with their correlation coefficients for galena dissolution at different temperatures by $10 \mathrm{M} \mathrm{HNO}_{3}$.

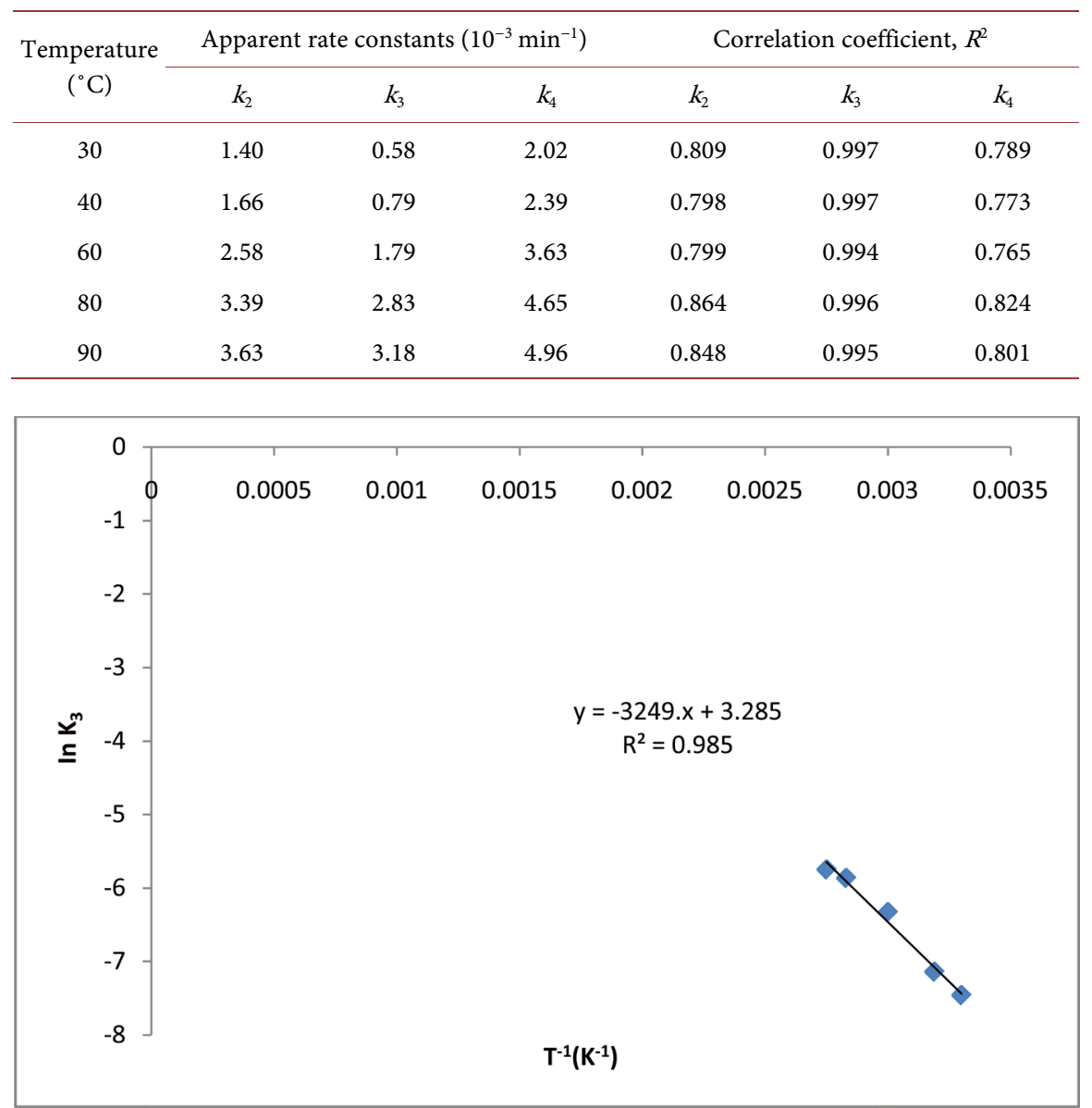

Figure 14. Arrhenius plot of reaction rate against reciprocal of temperature. 


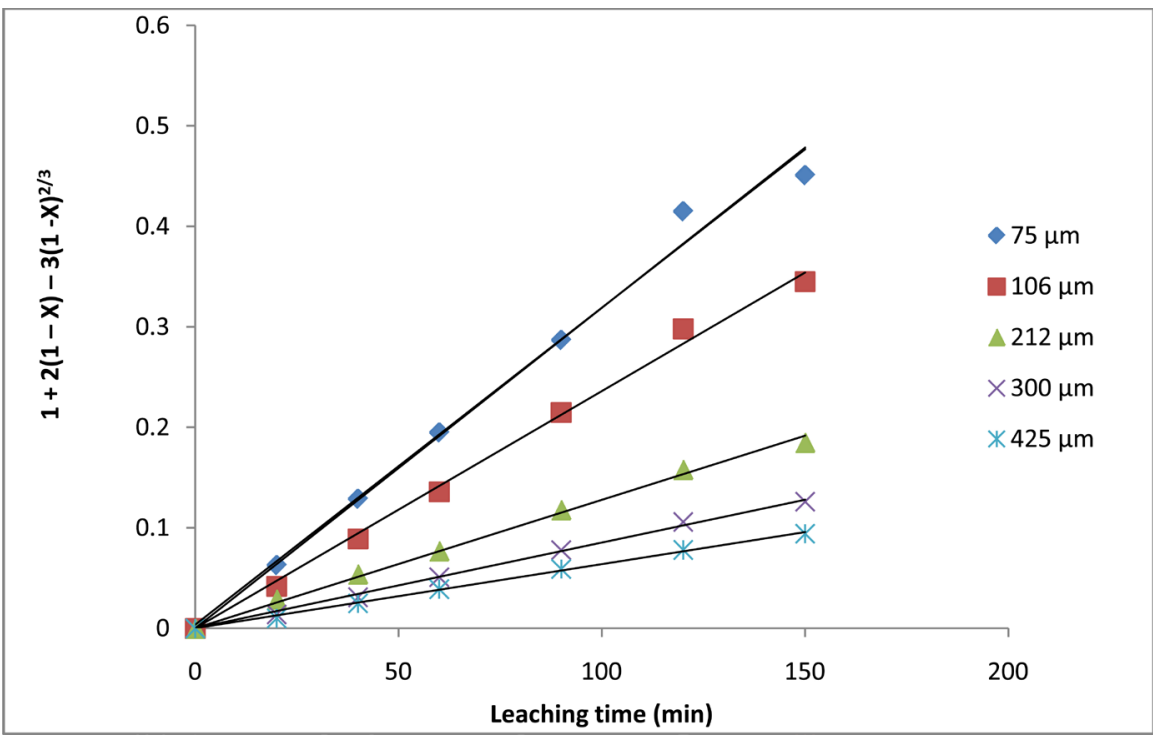

Figure 15. Plot of $1+2(1-X)-3(1-X)^{2 / 3}=k t$ vs. leaching time at various particle diameters for data presented in Figure 7.

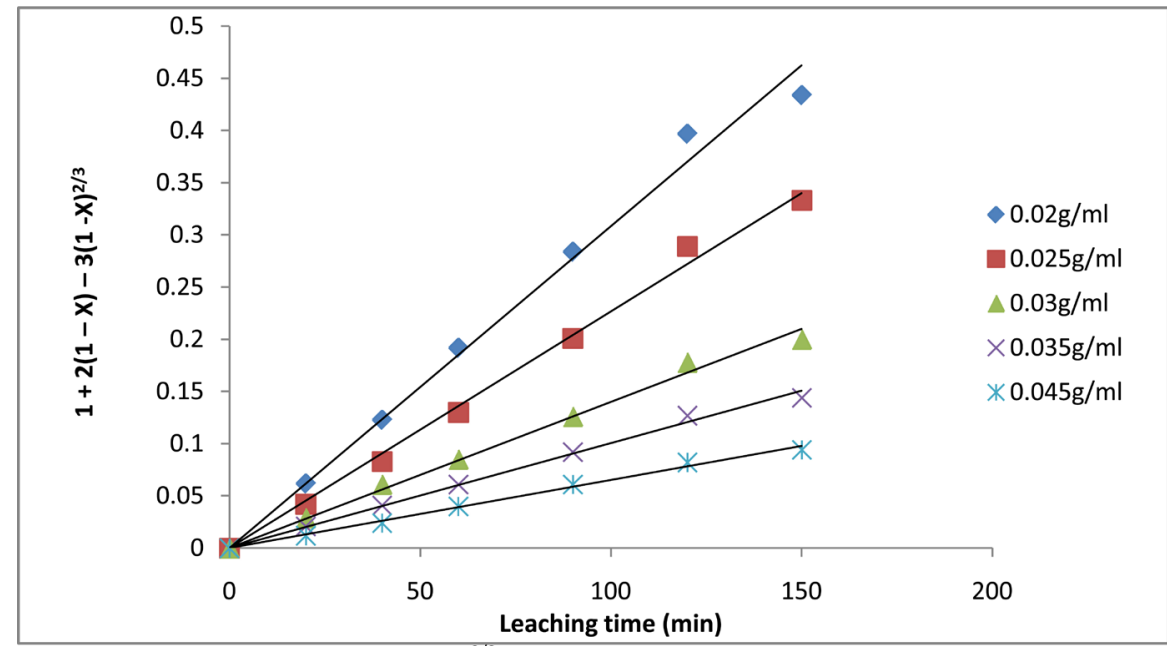

Figure 16. Plot of $1+2(1-X)-3(1-X)^{2 / 3}=k t$ vs. leaching time at various solid/liquid ratios for data presented in Figure 8.

process could either be predicted from plots of the kinetic equations or from the activation energy.

In general and as demonstrated by Aydogan et al. [18], it has been accepted that a diffusion-controlled process is characterized by a slight dependence on temperature, while the chemically controlled process is strongly dependent on temperature. The reason being that diffusion coefficient, $D$, is linearly dependent on temperature formulated as: $k=A \mathrm{e}^{-E_{a} / R T}$, where $A$ is the Arrhenius constant, $E_{a}$ is the activation energy, $R$ is the Boltzmann constant and $T$ is the absolute temperature. The activation energy calculated for this study appears to be the lowest compared to other reported works as summarized in Table 4. The galena ore obtained from Abakaliki can therefore be said to be kinetically 
Table 4. Some reported activation energies for galena leaching by different leaching systems.

\begin{tabular}{cccc}
\hline Origin of galena & Leachant & $E_{a}(\mathrm{KJ} / \mathrm{mol})$ & References \\
\hline Sivas, Turkey & $0.5 \mathrm{M} \mathrm{HNO}_{3} / 1 \mathrm{M} \mathrm{H}_{2} \mathrm{O}_{2}$ & 42.26 & Aydogan et al. [13] \\
Sivas, Turkey & $3 \mathrm{M} \mathrm{CH}_{3} \mathrm{COOH} / 0.5 \mathrm{M} \mathrm{H}_{2} \mathrm{O}_{2}$ & 65.60 & Aydogan et al. [18] \\
Bor, Yugoslavia & $2 \mathrm{M} \mathrm{H}_{2} \mathrm{O}_{2} / 2 \mathrm{M} \mathrm{H}_{2} \mathrm{SO}_{4}$ & 60.00 & Antonijevic et al. [36] \\
Abakaliki, Nigeria & $8.06 \mathrm{M} \mathrm{H}_{2} \mathrm{O}_{2} / 8.06 \mathrm{M} \mathrm{HCl}^{2}$ & 40.55 & Baba and Adekola [31] \\
Abakaliki, Nigeria & $10 \mathrm{M} \mathrm{HNO}_{3}$ & 27.01 & This work \\
\hline
\end{tabular}

more favorable to leaching by $\mathrm{HNO}_{3}$ compared to other galena types.

According to Olanipekun [35], the rate controlling mechanism of heterogeneous dissolution process is often predicted from the plots of the kinetic equations, rather than the activation energy. Therefore, in order to determine the rate determining step for the present study, the kinetic curves in Figure 7 were also linearized by means of Equation (3). The values of the rate constants, $k_{4}$, were plotted against the reciprocal of the particle radii $\left(1 / r_{0}\right)$, yielding a linear relationship with a correlation coefficient of 0.995 (Figure 19). It is worthy of note that the plot of the rate constants as a function of the square of particle radii $\left(1 / r_{o}\right)^{2}$ did not give a linear relationship. This indicates that the surface chemical reaction was the rate controlling step during the dissolution. Hence, the diffusion of the $\mathrm{H}^{+}$ion was at higher rate because of the high transport number in aqueous solution [22].

\subsubsection{Dissolution Model}

From the effects of the solid/liquid ratio (Figure 17) and particle diameters (Figure 18) on galena dissolution in $10 \mathrm{M} \mathrm{HNO}_{3}$ solution, the apparent rate constants, $k_{6}$ and $k_{7}$ were evaluated, respectively.

The solid/liquid ratio and initial particle size $\left(d_{p}\right)$ were found to be inversely proportional to 1.99 power $(S / L)^{-1.99}$ and 0.94 power $\left(d_{p}^{-0.94}\right)$, respectively. Hence, the proposed model equation for galena dissolution by $10 \mathrm{M} \mathrm{HNO}_{3}$ solution at $90^{\circ} \mathrm{C}$ is consistent with the following relation:

$$
1+2(1-X)-3(1-X)^{2 / 3}=k_{o} C_{\mathrm{HNO}_{3}}^{0.93}\left(d_{p}\right)^{-0.94}\left(\rho \frac{S}{L}\right)^{-1.99}(w)^{0.79} \mathrm{e}^{(-27012 / R T)} t
$$

where $\rho$ is the ore density (Baba and Adekola, 2011). $k_{o}$ is a reaction constant, which can be determined from the fraction of galena ore dissolved, $X$ at a given time, $t$. The parameter, $X$ is determined experimentally. For instance, at $90^{\circ} \mathrm{C}$, the value of $X=0.845$ ( $84.5 \%$ dissolution); $k_{o}$ is calculated to be $3.54 \times 10^{8}$. The value of $k_{o}$, however, is found to vary depending on the leaching systems/conditions [13] [37].

\subsection{Characterization of the Residual Product}

\subsubsection{SEM Analysis of Galena Leached with $10 \mathrm{M} \mathrm{HNO}_{3}$}

The scanning electron micrograph (SEM) of galena leached with $10 \mathrm{M} \mathrm{HNO}_{3}$ 


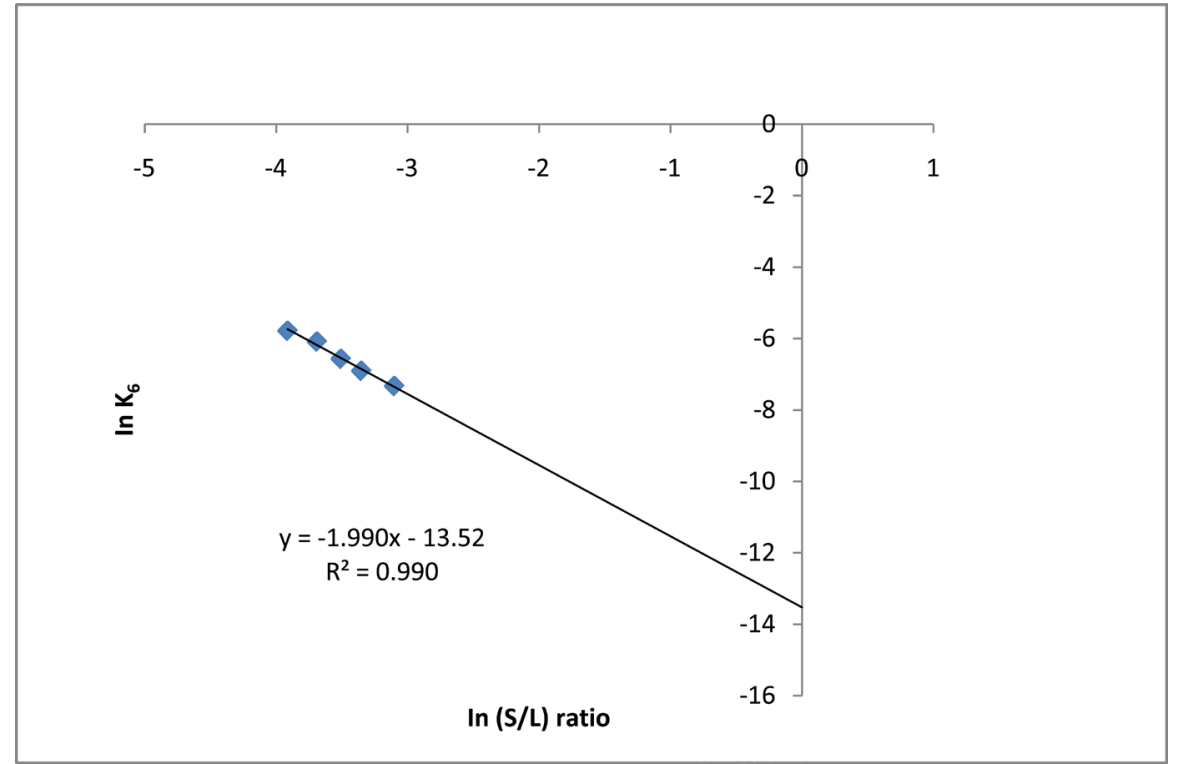

Figure 17. Plot of $\operatorname{In} k_{6}$ vs. $\operatorname{In}(S / L)$, for determining order of solid/liquid ratio.

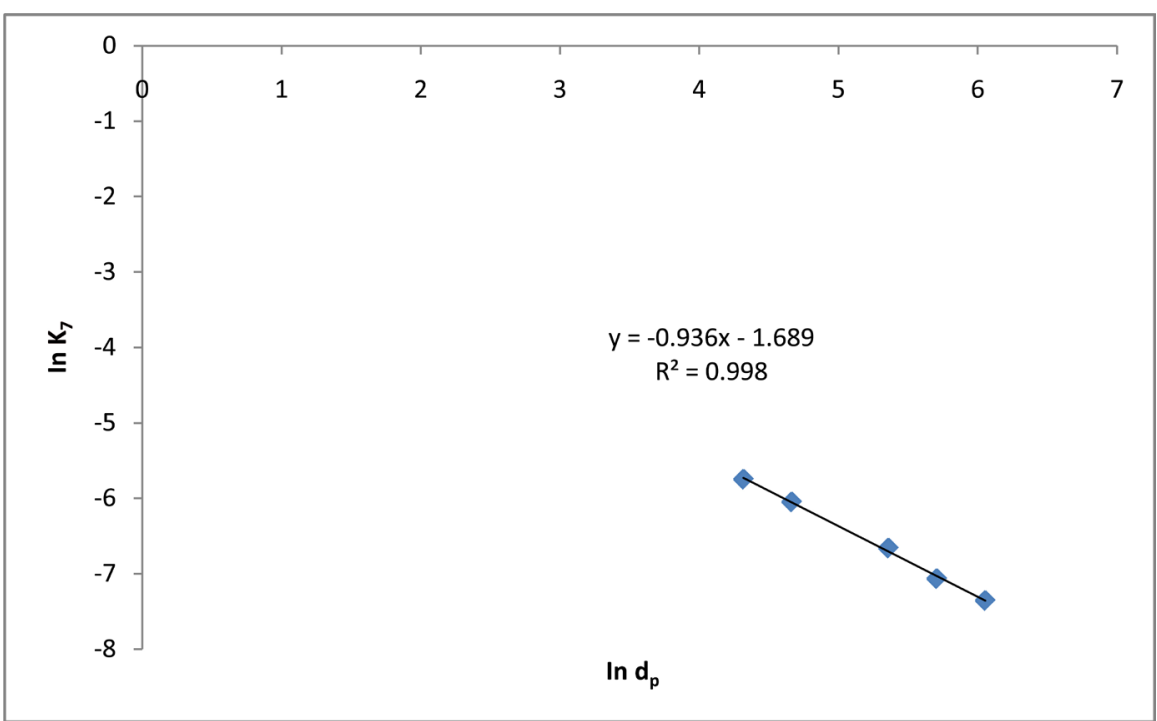

Figure 18. Plot of $\operatorname{In} k_{7}$ vs. In $d_{p}$, for determining order of initial particle diameter.

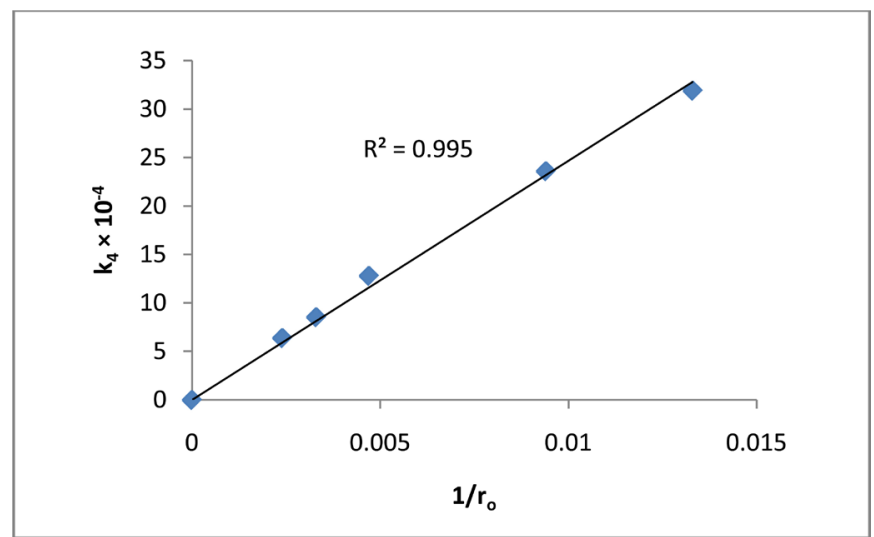

Figure 19. Dependence of rate constant, $k_{4}$, on $1 / r_{o}$. 
was obtained with magnifications of $150 \times, 500 \times$ and $1000 \times$ respectively as shown in Figure 20. The average cell diameter ranges from $26 \mu \mathrm{m}$ to $104 \mu \mathrm{m}$ while the average cell density ranges from $0.0938 \mathrm{cell} / \mathrm{mm}$ to $0.156 \mathrm{cell} / \mathrm{mm}$. The results above indicate an increase in the diameter of the particles and a corresponding decrease in density as the particle volume automatically increases and therefore decreases the specific gravity [28]. The micrographs of the leaching residues show a progressive increase in the roughness of the solid and also an increase in the amount of elemental sulphur covering the particle surfaces [38]. The particles have irregular shapes and may be poorly crystalline due to acid attack.

\subsubsection{XRD Analysis of Galena Leached with $10 \mathrm{M} \mathrm{HNO}_{3}$}

The analysis of galena leached with $10 \mathrm{M} \mathrm{HNO}_{3}$ at $90^{\circ} \mathrm{C}$ by X-ray diffraction gives a description of the mineral phases present in the residue. Table 5 present the results of the X-ray diffractogram of the residue with important compounds identified. The result showed two major and one minor peaks at 4.51, 2.26, and $1.51 \AA$, respectively. The XRD data revealed the presence of gahnite and anglesite as shown in Figure 21. The XRD result agrees with the SEM result of the residue. In summary, the overall dissolution reaction of galena in $\mathrm{HNO}_{3}$ solution can be described by the following stoichiometry:

$$
\underset{\text { (galena) }}{\mathrm{PbS}_{(\mathrm{s})}}+2 \mathrm{H}_{(\mathrm{aq})}^{+} \rightleftarrows \underset{(\cong 85 \% \text { released into solution })}{\mathrm{Pb}_{(\mathrm{aq})}^{2+}}+\mathrm{H}_{2} \mathrm{~S}_{(\mathrm{g})}
$$

\section{Conclusions}

Based on the results of the characterization and leaching investigations undertaken in this study, the following conclusions can be drawn:

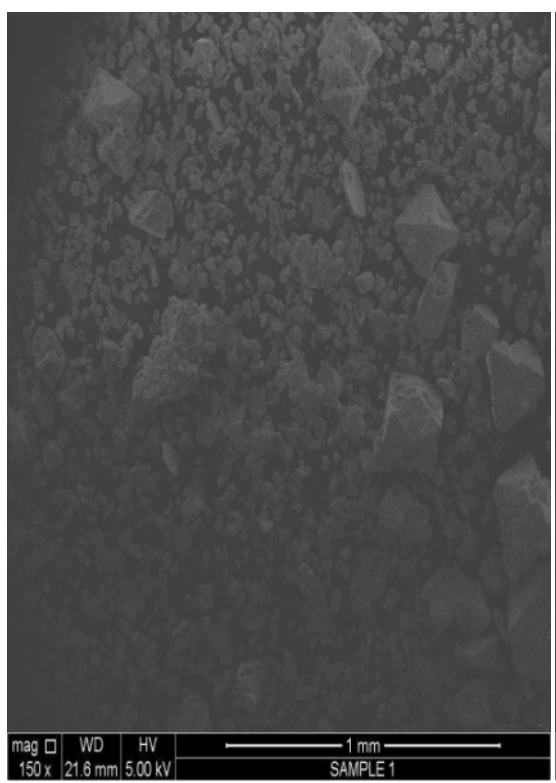

(a)

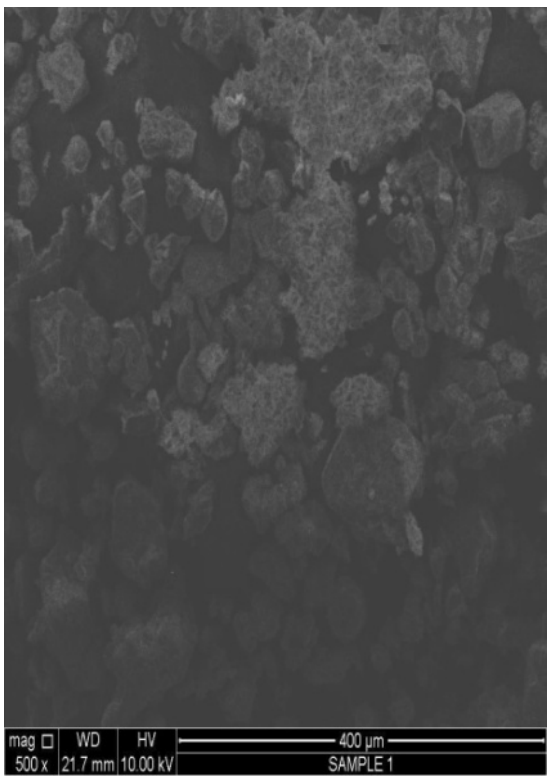

(b)

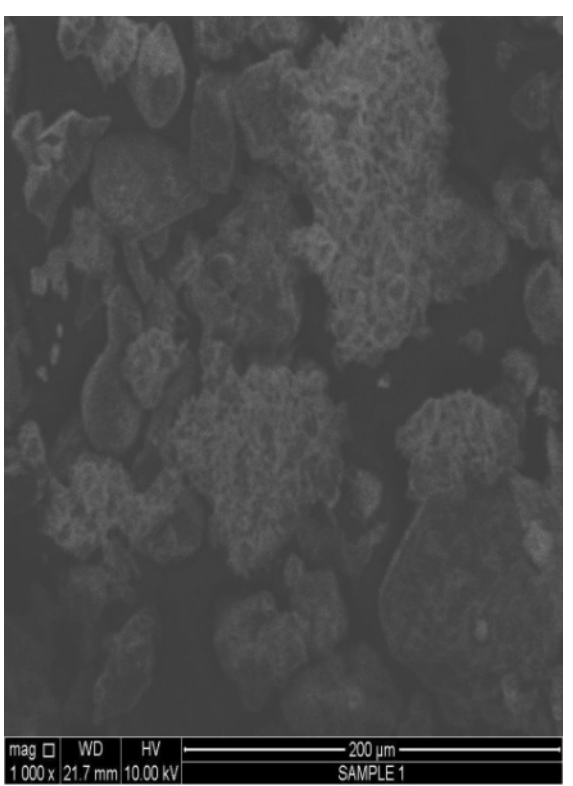

(c)

Figure 20. SEM image of galena leached with $10 \mathrm{M} \mathrm{HNO}_{3}$ with magnifications of $150 \times(\mathrm{a}), 500 \times(\mathrm{b})$ and $1000 \times(\mathrm{c})$ respectively. 
Table 5. The X-ray diffraction data of the galena ore leached with $10 \mathrm{M} \mathrm{HNO}_{3}$ showing the angle $2 \theta$ and d-values of the compounds identified, with their relative intensity (\%).

\begin{tabular}{ccccc}
\hline $2 \theta$ & $\mathrm{d}$-Value $(\AA)$ & Compound & Intensity $(\%)$ & JCPDS file No. \\
\hline 19.67 & 4.51 & Gahnite $\left(\mathrm{Zn}_{8} \mathrm{Al}_{16} \mathrm{O}_{32}\right)$ & 100.00 & $96-900-7041$ \\
26.81 & 3.33 & Anglesite $\left(\mathrm{Pb}_{4} \mathrm{~S}_{4} \mathrm{O}_{16}\right)$ & 15.06 & $96-900-4485$ \\
27.79 & 3.21 & Anglesite $\left(\mathrm{Pb}_{4} \mathrm{~S}_{4} \mathrm{O}_{16}\right)$ & 22.81 & $96-900-4485$ \\
29.79 & 3.00 & Anglesite $\left(\mathrm{Pb}_{4} \mathrm{~S}_{4} \mathrm{O}_{16}\right)$ & 18.20 & $96-900-4485$ \\
38.04 & 2.37 & Gahnite $\left(\mathrm{Zn}_{8} \mathrm{Al}_{16} \mathrm{O}_{32}\right)$ & 24.14 & $96-900-7041$ \\
39.80 & 2.26 & Gahnite $\left(\mathrm{Zn}_{8} \mathrm{Al}_{16} \mathrm{O}_{32}\right)$ & 61.88 & $96-900-7041$ \\
43.85 & 2.06 & Anglesite $\left(\mathrm{Pb}_{4} \mathrm{~S}_{4} \mathrm{O}_{16}\right)$ & 22.95 & $96-900-4485$ \\
57.49 & 1.60 & Gahnite $\left(\mathrm{Zn}_{8} \mathrm{Al}_{16} \mathrm{O}_{32}\right)$ & 11.79 & $96-900-7041$ \\
61.34 & 1.51 & Gahnite $\left(\mathrm{Zn}_{8} \mathrm{Al}_{16} \mathrm{O}_{32}\right)$ & 26.13 & $96-900-7041$ \\
\hline
\end{tabular}

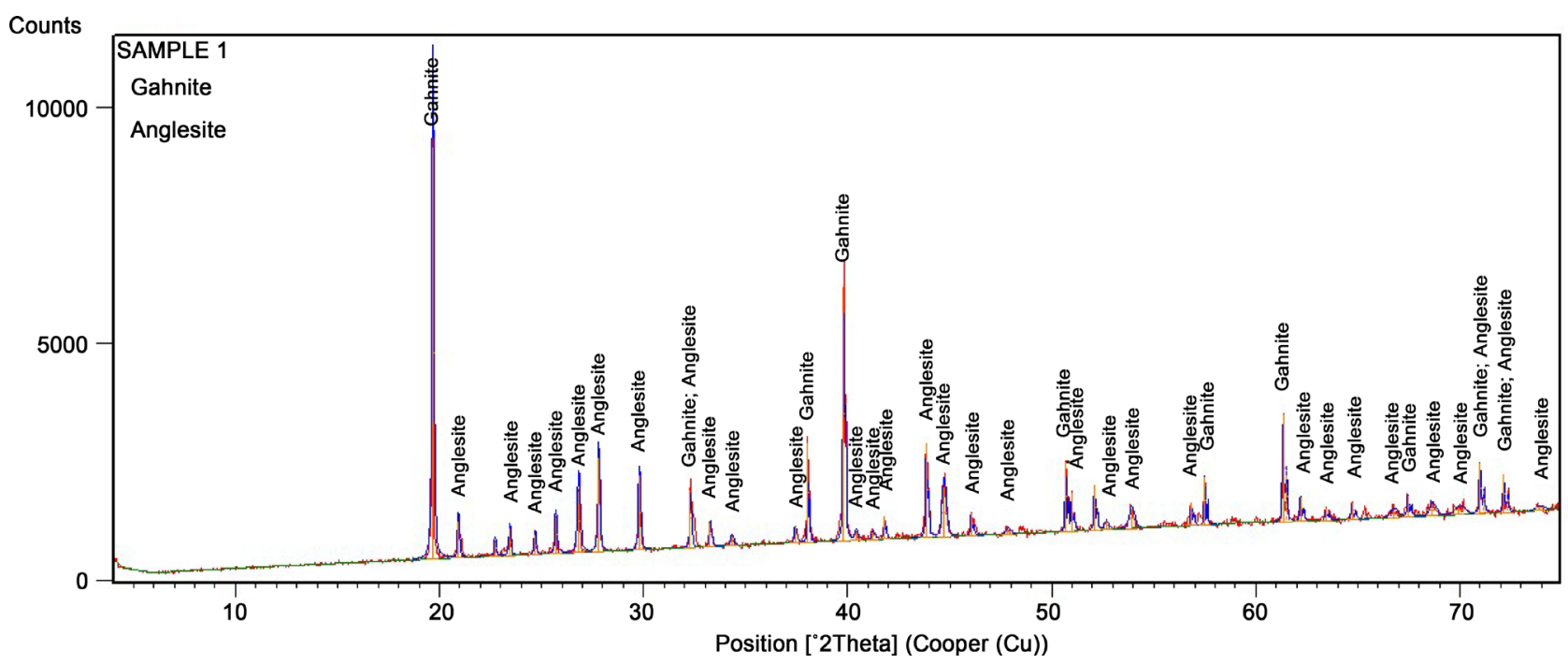

Figure 21. X-ray diffraction pattern of the post-leached residue of galena after leaching for 150 minutes at $90^{\circ} \mathrm{C}$ with $10 \mathrm{M} \mathrm{HNO}_{3}$.

1) The X-ray fluorescence data showed that the galena ores used in the study exist mainly as $\mathrm{PbS}$. Lead $(\mathrm{Pb})$ was detected as the major metal for galena with metals such as $\mathrm{Na}, \mathrm{Ca}, \mathrm{Fe}, \mathrm{Zn}, \mathrm{Al}$ and $\mathrm{Mg}$ occurring as minor elements. The $\mathrm{XRD}$ analysis also confirmed the originality of the galena ore as it revealed that galena exists mainly as lead sulphide (PbS). The Fourier transform infrared (FTIR) analysis also supported the XRF and XRD analysis by revealing the presence of sulphur. The scanning electron micrograph (SEM) analysis revealed a high level of crystallinity of the ore.

2) The leaching investigation clearly showed that galena dissolution in nitric acid $\left(\mathrm{HNO}_{3}\right)$ increases with increasing concentration of nitric acid, temperature and stirring rate, and decreases with increasing particle diameter and solid/liquid ratio. In $10 \mathrm{M} \mathrm{HNO}_{3}$ at a temperature of $90^{\circ} \mathrm{C}$ using $75 \mu \mathrm{m}$ particle diameter with solid/liquid ratio of $20 \mathrm{~g} / \mathrm{L}$ and stirring speed of $540 \mathrm{rpm}$, about $84.5 \%$ of galena was dissolved in 150 minutes. The values of activation energy, 
order of reaction and Arrhenius constant calculated at the conditions above for galena were $27.01 \mathrm{KJ} / \mathrm{mol}, 0.93,26.71 \mathrm{~s}^{-1}$.

3) The results of the dissolution studies indicated that the data fitted the shrinking core model for the diffusion controlled mechanism, with surface chemical reaction as the rate controlling step. This is consistent with the following relation:

$1+2(1-X)-3(1-X)^{2 / 3}=k_{0} C_{\mathrm{HNO}_{3}}^{0.93}\left(d_{p}\right)^{-0.94}\left(\rho \frac{S}{L}\right)^{-1.99}(w)^{0.79} \mathrm{e}^{(-27012 / R T)} t$; where $k_{0}$ is the reaction constant, which can be determined experimentally.

4) The post-leaching residue was found to be constituted of gahnite and anglesite.

\section{References}

[1] Da Silva, G. (2004) Kinetics and Mechanism of the Bacterial and Ferric Sulphate Oxidation of Galena. Hydrometallurgy, 75, 99-110.

https://doi.org/10.1016/j.hydromet.2004.07.001

[2] Ukpong, E.E. and Olade, M.A. (1979) Geochemical Surveys for Lead-Zinc Mineralization, Southern Benue Trough, Nigeria. Transactions of Institute of Mining and Metallurgy, 88B, 81-92.

[3] Rahman, M.A.O. (2004) Nigeria's Minerals Endowment and Sustainable Development. 2nd Mosobalaje Oyawoye Endowed Faculty of Science Lecture, University of Ilorin, Unilorin Press, Illorin, 1-40.

[4] Baird, C. and Cann, N. (2012) Environmental Chemistry. 5th Edition, W. H. Freeman and Company, New York.

[5] Parker, R.B. (2005) The New Cold-Molded Boatbuilding: From Lofting to Launching. Wooden Boat Publications, Brooklin.

[6] Krestovnikoff, M. and Halls, M. (2006) Scuba Diving. Dorling Kindersley, London.

[7] Jensen, C.F. (2013) Online Location of Faults on AC Cables in Underground Transmission. Springer, Berlin.

[8] Feursternau, M.C., Nebo, C.O., Elango, B.V. and Han, K.H. (1987) The Kinetics of Leaching Galena with Ferric Nitrate. Metallurgical and Materials Transactions $B$, 18, 25-30.

[9] Awakura, Y., Kamei, S. and Majima, H. (1980) A Kinetic Study of Non-Oxidative Dissolution of Galena in Aqueous Acid Solution. Metallurgical and Materials Transactions B, 11, 377-381. https://doi.org/10.1007/BF02676882

[10] Olanipekun, E.O. (2000) Quantitative Leaching of Galena. Bulletin of the Chemical Society of Ethiopia, 14, 25-32. https://doi.org/10.4314/bcse.v14i1.71994

[11] Makita, M., Esperon, M., Lopez, B.P. and Orrantia, E. (2004) Reduction of Arsenic Content in a Complex Galena by Acidithiobacillus ferrooxidans. BMC Biotechnology, 4, 22-38. https://doi.org/10.1186/1472-6750-4-22

[12] Wang, S., Fang, Z., Wang, Y. and Chen, Y. (2003) Electronegative Leaching of Galena with Ferric Chloride. Minerals Engineering, 16, 869-872.

[13] Aydogan, S., Erdemoglu, M., Ucar, G. and Aras, A. (2007) Kinetics of Galena Dissolution in Nitric Acid Solutions with Hydrogen Peroxide. Hydrometallurgy, 88, 52-57. https://doi.org/10.1016/j.hydromet.2007.03.005

[14] Warren, G.W., Kim, S. and Henein, H. (1986) The Effect of Chloride Ion on the 
Ferric Chloride Leaching of Galena Concentrate. Metallurgical and Materials Transactions B, 18, 59. https://doi.org/10.1007/BF02658432

[15] Baba, A.A. and Adekola, F.A. (2011) Comparative Analysis of the Dissolution Kinetics of Galena in Binary Solutions of $\mathrm{HCl} / \mathrm{FeCl}_{3}$ and $\mathrm{HCl} / \mathrm{H}_{2} \mathrm{O}_{2}$. International Journal of Minerals, Metallurgy and Materials, 18, 9-17. https://doi.org/10.1007/s12613-011-0393-1

[16] Liu, J., Aruguete, D.M., Jinschek, J.R., Rimstidt, J.D. and Hochella, M.F. (2008) The Non-Oxidative Dissolution of Galena Nano-Crystals: Insights into Mineral Dissolution Rates as a Function of Grain Size, Shape, and Aggregation State. Geochimica et Cosmochimica Acta, 72, 5984-5996. https://doi.org/10.1016/j.gca.2008.10.010

[17] Gerson, R.A. and O'Dea, A.R. (2003) A Quantum Chemical Investigation of the Oxidation and Dissolution Mechanism of Galena. Geochimica et Cosmochimica Acta, 67, 813-822.

[18] Aydogan, S., Erdemoglu, M., Ucar, G. and Aras, A. (2007) Dissolution Kinetics of Galena in Acetic Acid Solutions with Hydrogen Peroxide. Hydrometallurgy, 89, 189-195. https://doi.org/10.1016/j.hydromet.2007.07.004

[19] Baba, A.A. (2008) Recovery of Zinc and Lead from Sphalerite, Galena and Waste Materials by Hydrometallurgical Treatments. University of Ilorin, Ilorin, 675.

[20] Levenspiel, O. (1972) Chemical Reaction Engineering. 2nd Edition, John Wiley \& Sons, New York.

[21] Merwe, W. (2003) Dissolution of Sphalerite Minerals from Rosh Pinah Tailings, Magister Scientiae. Faculty of Natural and Agric. Sciences, University of Pretoria, Pretoria, 106.

[22] Baba, A.A. and Adekola, F.A. (2012) A Study of Dissolution Kinetics of a Nigerian Galena Ore in Hydrochloric Acid. Journal of Saudi Chemical Society, 16, 377-386. https://doi.org/10.1016/j.jscs.2011.02.005

[23] Abraitts, P.K., Pattrick, R.A.D., Kelsall, G.H. and Vaughan, D.J. (2004) Acid Leaching and Dissolution of Major Sulphide Ore Minerals: Processes and Galvanic Effects in Complex System. Mining Magazine, 68, 343-351. https://doi.org/10.1180/0026461046820191

[24] Cisneros-Gonzalez, I., Oropeza-Guzman, M. and Gonzalez, T. (2000) Galena and Sphalerite Process in Acidic Chloride Media, Electrochemistry in Mineral and Metal Processing. Proceedings of the Electrochemical Society, No. 14, 248-254.

[25] Harvey, T.J. and Yen, W.T. (1998) The Influence of Chalcopyrite, Galena and Pyrite on the Selective Extraction of Zinc from Base Metal Sulphide Concentrates. Minerals Engineering, 11, 1-21. https://doi.org/10.1016/S0892-6875(97)00135-0

[26] Pacholewska, M. (2004) Bioleaching of Galena Flotation Concentrates. Physicochemical Problems of Mineral Processing, 38, 281-291.

[27] Hutchison, C.S. (1974) Laboratory Handbook of Petrography Techniques. John Wiley and Sons Inc., New York, 1-14.

[28] Bendou, S. and Amrani, M. (2014) Effect of Hydrochloric Acid on the Structural of Sodic-Bentonite Clay. Journal of Minerals and Materials Characterization and Engineering, 2, 404-413. https://doi.org/10.4236/jmmce.2014.25045

[29] Ajemba, R.O. and Onukwuli, O.D. (2012) Application of the Shrinking Core Model to the Analysis of Alumina Leaching from Ukpor Clay using Nitric Acid. International Journal of Engineering Research \& Technology, 1, 1-13.

[30] Dutrizac, J.E. and MacDonald, R.J.C. (1977) CIM Annual Volume, 186-194.

[31] Baba, A.A. and Adekola, F.A. (2010) Hydrometallurgical Processing of a Nigerian 
Sphalerite in Hydrochloric Acid: Characterization and Dissolution Kinetics. $H y$ drometallurgy, 101, 69-75. https://doi.org/10.1016/j.hydromet.2009.12.001

[32] Habashi, F. (2005) Hydrometallurgy of Lead. Metallurgia, 59, 114-118.

[33] Khalique, A., Akram, A., Ahmed, A.S. and Hamid, N. (2005) Effect of Sodium Chloride on Dissolution of Galena in Aqueous Acid Solution. Pakistan Journal of Scientific and Industrial Research, 48, 236-239.

[34] Leao, V.A., Souza, A.D., Pina, P.S., Silva, C.A. and Siqueira, P.F. (2007) The Leaching Kinetics of a Zinc Sulphide Concentrate in Acid Ferric Sulphate. Hydrometallurgy, 89, 72-81. https://doi.org/10.1016/j.hydromet.2007.05.008

[35] Olanipekun, E.O. and Oderinde, R.A. (1999) Hydrochloric Acid Leaching of Sphalerite in the Presence of an Oxidizing Agent. Pakistan Journal of Scientific and Industrial Research, 42, 204-208.

[36] Antonijevic, M.M., Jankovic, Z.D. and Dimitrijevic, M.D. (2004) Kinetics of Chalcopyrite Dissolution by Hydrogen Peroxide in Sulphuric Acid. Hydrometallurgy, 71, 329-334. https://doi.org/10.1016/S0304-386X(03)00082-3

[37] Fuerstenau, M.C., Nebo, C.O., Elango, B.V. and Han, K.N. (1986) The Kinetics of Leaching Galena with Ferric Nitrate. Metallurgical and Materials Transactions $B$, 18, 25-30. https://doi.org/10.1007/BF02658428

[38] Souza, A.D., Pina, P.S. and Leao, V.A. (2007) Bioleaching and Chemical Leaching as an Integrated Process in the Zinc Industry. Minerals Engineering, 20, 591-599.

https://doi.org/10.1016/j.mineng.2006.12.014 